\title{
Site-specific Polymer Attachment to HR2 Peptide Fusion Inhibitors against HIV-1 Decreases Binding Association Rates and Dissociation Rates rather than Binding Affinity
}

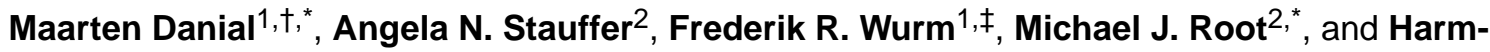 \\ Anton Klok ${ }^{1}$ \\ ${ }^{1}$ Institut des Matériaux and Institut des Sciences et Ingéniere Chimiques, École Polytechnique \\ Fédérale de Lausanne, Laboratoire des Polymères, Bâtiment MXD, Station 12,1015 Lausanne, \\ Switzerland ${ }^{2}$ Department of Biochemistry and Molecular Biology, Thomas Jefferson University, \\ 233 South 10th Street, 19107 Philadelphia, PA, USA
}

\section{Abstract}

\begin{abstract}
A popular strategy to overcome the limited plasma half-life of peptide heptad repeat 2 (HR2) fusion inhibitors against HIV-1 is through conjugation with biocompatible polymers such as poly(ethylene glycol) (PEG). However, despite improved resistance to proteolysis and reduced renal elimination, covalent attachment of polymers often causes a loss in therapeutic potency. In this study, we investigated the molecular origins of the loss in potency upon conjugation of linear, mid-functional and hyperbranched PEG-like polymers to peptides that inhibit HIV-1 - host cell membrane fusion. Fluorescence binding assays revealed that polymer conjugation imparted mass transport limitations that manifested as coexistent slower association and dissociation rates from the gp41 target on HIV-1. Furthermore, reduced association kinetics rather than affinity disruption was responsible for the loss in antiviral potency. Finally, the binding assays indicated that the unmodified HR2-derived peptide demonstrated diffusion-limited binding. The observed high potency of the unmodified peptide in HIV-1 inhibition assays was therefore attributed to rapid peptide conformational changes upon binding the gp41 prehairpin structure. This study emphasizes that the view in which polymer ligation to therapeutic peptides inadvertently leads to loss in potency due to a loss in binding affinity requires scientific verification on a case-by-case basis, and that high peptide potency may be due to rapid target-binding events.
\end{abstract}

\section{Graphical Abstract}

\footnotetext{
*Corresponding Authors: Maarten Danial: Maarten.Danial@csiro.au, Michael J. Root: Michael.Root@jefferson.edu.

†Present address: CSIRO Manufacturing, Ian Wark Laboratory, Bayview Ave., Clayton VIC 3168, Australia.

FPresent address: Max Planck Institut für Polymerforschung, Ackermannweg 10, 55128 Mainz, Germany.

ASSOCIATED CONTENT

Synthesis schemes, peptide - polymer conjugate characterization by NMR, HPLC and MALDI-TOF and additional figures summarizing binding thermodynamics and kinetics of the peptide - polymer conjugates to 5-Helix are included in the Supporting Information. This material is available free of charge via the Internet at http://pubs.acs.org.

Author Contributions

The manuscript was written through contributions of all authors. All authors have given approval to the final version of the manuscript.
} 


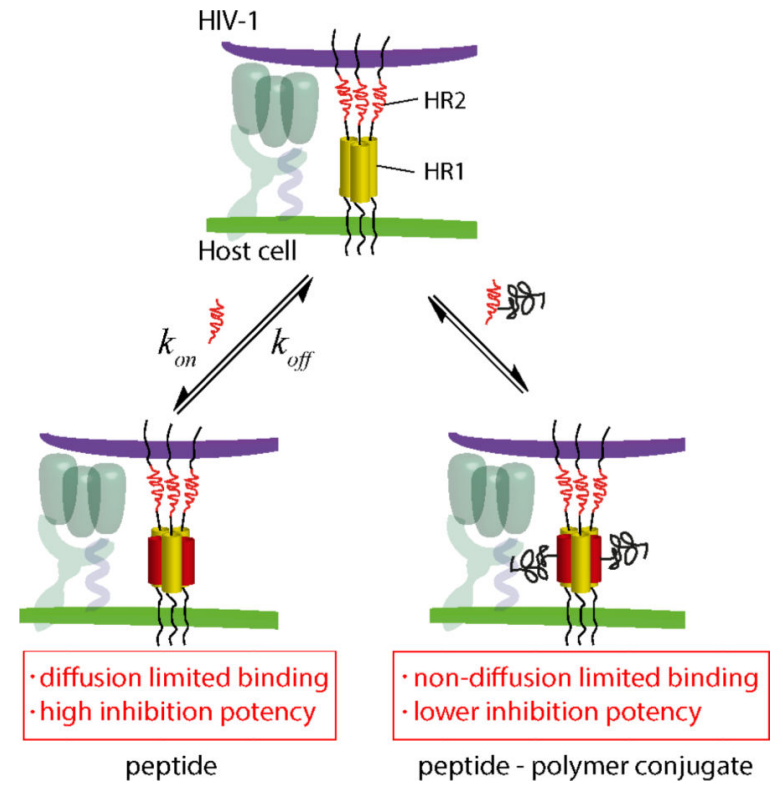

\section{INTRODUCTION}

Therapeutic peptides and proteins have become indispensible in modern medicine due to their high specificity for biological targets and high pharmaceutical efficacy. ${ }^{1}$ However, the advantages of applying therapeutic peptides and proteins are often overshadowed by several major drawbacks that hamper their administration. This includes the susceptibility of peptide and protein drugs to rapid renal clearance, proteolytic degradation, potential immunogenicity, and non-specific adsorption to proteins (e.g. serum albumin) and cellular membranes, which ultimately causes a reduced circulation life-time and bioavailability. A major strategy to improve the stability and circulation life-time of peptide / protein therapeutics is via covalent attachment of a synthetic hydrophilic polymer such as poly(ethylene glycol) (PEG). ${ }^{2,3}$ PEG conjugation (or PEGylation) provides a physical barrier towards proteolytic enzymes and increases the hydrodynamic volume of the peptide / protein therapeutic thereby reducing proteolysis and renal elimination, respectively. ${ }^{4,5} \mathrm{In}$ addition, the ligation of branched PEG results in conjugates with improved properties via the 'umbrella effect' such as increased resistance to proteolytic degradation and prolonged halflives that surpass those of proteins modified with linear PEG derivatives. ${ }^{2,6}$

One class of peptide drugs to have shown therapeutic value are fusion inhibitors that block infection of HIV type 1 (HIV-1). These peptides are derived from the heptad repeat 1 (HR1) and heptad repeat 2 (HR2) domains of the HIV-1 glycoprotein gp41. ${ }^{7-12}$ In mediating viral entry into target cells, the HR1 and HR2 domains from three gp41s associate in a trimer-ofhairpins conformation that brings the viral and cellular membranes into close proximity for membrane fusion. Fusion inhibitors derived from these domains act in a dominant negative fashion to disrupt formation of the trimer-of-hairpins, thereby preventing HIV-1 host-cell entry at a primary stage of infection before viral RNA is integrated into the host cell genome. Currently, one fusion inhibitor, T20 (Fuzeon $\left.{ }^{\circledR}\right)$, is FDA approved and utilized primarily as salvage therapy for patients infected with multi-drug resistant HIV-1. However, 
drawbacks such as high doses $(2 \times 90 \mathrm{mg} \text { daily subcutaneous injections })^{13}$ accompanied with high costs of production and low plasma half-life of the peptide drug, limits the clinical utility of T-20. ${ }^{14}$ Furthermore, the emergence of T-20 resistant HIV-1 strains as rapidly as 14 days after the start of administration, renders T-20 less effective for long-term use. ${ }^{15}$ Efforts to produce anti-HIV PEGylated peptide fusion inhibitors with longer circulation life times have been pursued, often leading to severe loss in efficacy. ${ }^{16-18}$ Moreover, our own efforts have demonstrated that conjugation of linear PEGs to peptides resulted in lower anti-fusion efficacies relative to the unmodified peptide, despite endeavors to attach the polymer at sites on the peptide that are not involved in binding gp41. ${ }^{19,20}$ While the consequences of PEGylation on anti-fusion efficacy have been identified, the details on the inhibitory process as well as implications on inhibitory binding affinity and kinetics have not. Answering these key questions would provide valuable insight into a fundamental inhibitory process mediated by peptide - polymer conjugates against HIV-1 membrane fusion and could have broad implications for the judicious design and application of myriad polymer conjugates against other enveloped viruses that infect cells via similar mechanisms.

In this contribution, the anti-HIV-1 fusion potency as well as the affinity and binding kinetics of a library of peptide - polymer conjugates were investigated. The types of conjugates examined include peptides ligated to linear PEGs as well as to branched PEGlike polymers known as polyglycerols (PGs), which have demonstrated excellent biocompatibility, non-toxicity and have a superior thermal and oxidative stability as compared to their PEG counterparts. ${ }^{21-23}$ Taken together, this study provides thermodynamic and kinetic insights into the HIV-1 fusion inhibition process mediated by a novel set of peptide - polymer conjugates.

\section{RESULTS AND DISCUSSION}

The design and structure of the peptide - polymer conjugates investigated in this study is illustrated in Figure 1. The sequence of a parent C41 peptide was derived from the HR2 domain of gp 41 as defined by Weissenhorn et al. ${ }^{24}$ The design of $\mathrm{C} 41$ encompasses elements from the sequence of T- $20^{13}$ (also known as DP- $178^{8}$ ) with additional residues at the N-terminal end including the deep-pocket binding residues Trp-2 and Ile-6, which have been shown to improve anti-HIV fusion inhibition efficacy. ${ }^{25}$ In addition, the $\mathrm{C} 41$ peptide exhibits a truncation of residues relative to $\mathrm{T}-20$ at the $\mathrm{C}$-terminal end as these residues fall outside the heptad repeat region. To facilitate site-specific polymer conjugation, four cysteine-containing $\mathrm{C} 41$ peptide variants were synthesized, which included peptides modified with a cysteine at the $\mathrm{N}$-terminus and $\mathrm{C}$-terminus as well as at positions replacing Ser-15 and Ser-20 (Figure 1b). As illustrated in Figure 1c, polymer conjugation to S15C would result at position $c$ of the helical wheel while polymer conjugation to S20C would result at position $a$ of the helical wheel. This implies that a polymer conjugated to $\mathrm{S} 15 \mathrm{C}$ would project away from the binding interface with the HR1 domain on gp41 while a polymer conjugated S20C would project towards, and perhaps, interfere with the binding to HR1 domain on gp41 (Figure 1d). The choice of site-specific polymer conjugation at S15C, S20C combined with the $\mathrm{N}$ - and $\mathrm{C}$-terminal ends on the HR2 peptides would thereby permit elucidating the effects of conjugation on potency, binding affinity and binding kinetics. 
Following successful synthesis and purification of the cysteine modified C41 peptide variants, site-specific Michael-type addition ligation of the polymers was performed in aqueous buffer to generate a library of peptide - polymer conjugates. As Table 1 presents, the resulting conjugates include peptides modified with linear acrylate end-functionalized PEG750 (1, $\left.790 \mathrm{~g} \cdot \mathrm{mol}^{-1}\right)$ or PEG2000 (2, $\left.1960 \mathrm{~g} \cdot \mathrm{mol}^{-1}\right)$, a maleimide mid-functional poly(ethylene glycol-co-glycerol) copolymer (3, p(EG-co-G), $M_{\mathrm{n}}$ of $\left.1780 \mathrm{~g} \cdot \mathrm{mol}^{-1}\right)$ or a maleimide functionalized hyperbranched polyglycerol $\left(\mathbf{4}, h b \mathrm{PG}, M_{\mathrm{n}}=2050 \mathrm{~g} \cdot \mathrm{mol}^{-1}\right)$. The Supporting Information provides details on the synthesis and characterization of these compounds including gel permeation chromatography (GPC), NMR, HPLC and MALDITOF data (Table S1, Scheme S1 and S2 and Figure S1 - S8). While these polymers may not provide prolonged renal retention, conjugation of these relatively low molar mass polymers have shown to provide up to 3.4-fold increase in degradation half-life when incubated with the protease trypsin. ${ }^{19}$ Furthermore, conjugation of similar low molar mass polymers as described in this manuscript would provide valuable insights that would not easily accessible through conjugation of high molar mass polymers.

The inhibitory potency of the peptide - polymer conjugates was assessed in a single-cycle infectivity experiments using HIV-1 pseudotyped with Env ${ }_{\mathrm{HXB} 2}$ and equipped with a luciferase reporter gene. Target cells were human osteosarcoma (HOS)-CCR5 cells that the express CD4 receptor and the two prominent coreceptors, CCR5 $\left(\sim 10^{5}\right.$ cell $\left.^{-1}\right)$ and CXCR4 $\left(\sim 5 \times 10^{3}\right.$ cell $\left.^{-1}\right) .{ }^{26} \mathrm{IC}_{50}$ concentrations were determined via infectivity assays in which the HOS CCR5 cells were exposed to HIV- $1_{\mathrm{HXB} 2}$ in the presence of $0-1000 \mathrm{nM}$ of the C41 or peptide - polymer conjugate for a period of 48 hours. The $\mathrm{IC}_{50}$ values obtained in these experiments are summarized in Figure 2 and are presented in Table 2. The C41 peptide had the highest potency with an $\mathrm{IC}_{50}$ value at $0.23 \pm 0.04 \mathrm{nM}$. The negative controls (S20C peptide - polymer conjugates) exhibited no infection inhibition over the investigated concentration range (Figure S9) and confirmed previous observations made with syncytia assays. ${ }^{19,20}$

As observed in Figure 2, conjugation at the N-terminal, C-terminal and lateral (S15C) positions resulted in loss of potency that ranged from modest (2.3-fold) to large (59-fold). Both the site of polymer ligation as well as polymer architecture influenced potency. Comparison of the different PEG750 and PEG2000 conjugates demonstrated that for a given synthetic polymer, $\mathrm{N}$ - and $\mathrm{C}$-terminal $\mathrm{PEGylation}$ resulted in higher $\mathrm{IC}_{50}$ values compared to lateral (S15C) attachment of the PEG chains. This effect was more pronounced for Cterminal polymer conjugation (6.3- to 59-fold inhibitory potency loss relative to the unmodified $\mathrm{C} 41$ peptide) compared to $\mathrm{N}$-terminal polymer conjugation (4.7- to 30-fold inhibitory potency loss). Similar trends between peptide - oligoethylene glycol conjugates and unmodified T-20 were observed, where C-terminal PEG-6 conjugation resulted in an 8.5-fold potency loss and N-terminal PEG-6 conjugation resulted in a 2.9-fold potency loss. ${ }^{27}$ Comparison of the PEG2000, mid-functional P(EG-co-G) and $h b \mathrm{PG}$ conjugates provides insight into the influence of polymer architecture. Whereas the linear PEG2000 and mid-functional $\mathrm{P}(\mathrm{EG}-c o-\mathrm{G})$ conjugates have similar $\mathrm{IC}_{50}$ values, the $h b \mathrm{PG}$ conjugates show significantly reduced potencies with $\mathrm{IC}_{50}$ values of up to $13 \mathrm{nM}$ (59-fold higher than $\mathrm{IC}_{50}$ value of unmodified $\mathrm{C} 41$ peptide). 
In an attempt to explain the observed differences in HIV-1 inhibitory potency, the binding affinities of $\mathrm{C} 41$ and the corresponding polymer conjugates were interrogated in equilibrium experiments using a fluorescein-labeled 5-Helix protein as a gp41 model. The 5-Helix protein consists of three HR1 and two HR2 segments alternately linked to generate a structural mimic of the gp41 trimer-of-hairpins with one HR2 segment missing. The absence of this segment creates a binding site capable of strongly and specifically interacting with gp41 HR2-derived peptides as they would interact with the HR1 region when inhibiting HIV-1 entry. ${ }^{28}$ Dissociation constants $\left(K_{\mathrm{D}}\right)$ were determined using a fluorescence-based kinetic-exclusion assay as illustrated in Supporting Information (Figure S10). ${ }^{26}$ Briefly, solutions of fluorescein-labeled 5-Helix and peptide-polymer conjugate were preequilibrated before brief exposure to HR2-peptide-coated beads in the flow cell of a KinExA 3000 flow fluorimeter. The relative concentrations of unbound 5-Helix were determined by measuring the change in bead fluorescence before and after sample exposure. The results of these experiments are summarized in Figure 3 and Table 2.

For the most part, conjugation at the N- or C-terminus or at the lateral position $\mathrm{S} 15 \mathrm{C}$ had minimal effect (less than 2.5-fold) on binding affinity. For a given synthetic polymer, lateral attachment (S15C) had a greater impact on $K_{\mathrm{D}}$ values than attachment at either the $\mathrm{N}$ - or Cterminus. In fact, the largest disruption of binding affinity ( $\sim 8$-fold) was observed for S15C conjugation of the bulkier polymers P(EG-co-G) and hbPG. The pattern of affinity disruption, with lateral conjugation having the greatest impact, is opposite to that for potency loss, in which conjugation at the $\mathrm{N}$ - and $\mathrm{C}$-terminus exerted the larger effect. Indeed, inhibitory potencies and binding affinities were poorly correlated overall (Figure S11), and, thus, affinity disruption alone does not explain the effect of polymer conjugation on C41 inhibitory activity.

Fusion inhibitors like HR2 peptides bind gp41 during a short-lived intermediate state that exists between receptor activation of Env and trimer-of-hairpins formation. ${ }^{29}$ Consequently, the antiviral potencies of fusion inhibitors often depend on nonequilibrium parameters such as the rates of inhibitor association and dissociation and the lifetime of the intermediate state. ${ }^{26,30}$ To assess whether altered binding kinetics might explain how polymer conjugation influences $\mathrm{C} 41$ potency, association rate constants $\left(k_{\text {on }}\right)$ were measured by kinetic-exclusion assay. Experiments were performed as described above except that the 5Helix / peptide-polymer conjugates were incubated for only 7.2 seconds before exposure to HR2-peptide coated beads. ${ }^{26,30}$ Dissociation rate constants $\left(k_{\text {off }}\right)$ were then calculated from $K_{\mathrm{D}}$ and $k_{\text {on }}$ (equation 1 ).

$$
k_{\mathrm{off}}=K_{D} \cdot k_{\mathrm{on}}
$$

As shown in Table 2, $k_{\text {on }}$ values for the peptide - polymer conjugates were found to be 3- to 21-fold lower than the unmodified peptide C41 (Figure S12). For a given polymer conjugation site, there was no obvious correlation between polymer size and impact on association rate. However, the polymers appeared to exert a greater effect when conjugated to the lateral position compared to a terminal position (with the exception of C-terminal conjugation of hbPG). The calculated $k_{\text {off }}$ values were found to be 2- to 6-fold lower 
compared to $\mathrm{C} 41$. Unlike the impact on assocation rates, the reduction in dissocation rates showed no obvious correlation with polymer size and site of conjugation (Figure S13).

For HIV-1 fusion inhibitors, a decrease in association rate has been shown to correlate with a loss of potency. ${ }^{30}$ This observation reflects the lower probability that the inhibitor can diffuse up to and bind gp41 during the lifetime of the sensitive intermediate state. This mechanism likely accounts for some of the observed increase in $\mathrm{IC}_{50}$ values caused by polymer conjugation to $\mathrm{C} 41$ peptide. However the magnitudes of potency changes and their dependencies on conjugation sites are not quantitatively explained by altered association rates alone. Two other factors might contribute to these discrepancies. First, dissociation rates for peptide-polymer conjugates were less than that for unconjugated C41. Slower dissociation increases the likelihood of irreversible deactivation of inhibitor-bound gp41, thereby enhancing inhibitory potency. ${ }^{26}$ Hence, the expected reduction of antiviral potency due to a large decrease in association rate could be partially blunted by a decrease in dissociation rate. This reasoning might explain the magnitudes of potency disruption for S15C polymer-conjugated C41 peptides, which were lower than expected based solely on decreases in association rates. Second, access to the gp41 HR1 region exposed in the prehairpin state has been shown to be sterically hindered. ${ }^{31,32}$ Specifically, attaching protein cargoes to the $\mathrm{N}$ - or C-terminus of HR2-derived fusion inhibitor C37 decreased antiviral potency to an extent dependent on cargo size. Similar trends are observed for polymerconjugated $\mathrm{C} 41$ peptides, with the bulkier conjugates generally showing a greater decrease in potency for a given conjugation site. Geometric restrictions in binding gp41 are not recapitulated in the 5-Helix / C41 binding assay but are likely to play a larger role when polymers are conjugated at the $\mathrm{N}$ - and $\mathrm{C}$-termini compared to when they are conjugated in the lateral position. Indeed, such steric factors could account for the potency disruption of termini-conjugated peptides, which exceeds the disruptions predicted from alterations of association and dissociation rates alone.

Although the relative antiviral potencies of $\mathrm{C} 41$ peptide-polymer conjugates were not easily explained by their measured interaction parameters, the binding studies did reveal an unexpected impact of polymer conjugation. Compared to unconjugated $\mathrm{C} 41$, each peptide polymer conjugate displayed reduced rates for both association and dissociation, resulting in a only marginal increase in $K_{\mathrm{D}}$. These results contrast observations made by Plückthun and coworkers who have shown that PEGylated proteins exhibited a reduced affinity caused by a lowered $k_{\text {on }}$ while $k_{\text {off }}$ remained statistically indifferent to the unmodified protein. ${ }^{33,34}$ The difference might be understood by drawing a distinction between diffusional and nondiffusional steps in a biomolecular reaction. ${ }^{35,36}$ In terms of the interaction studied here, the peptide - polymer conjugate must first diffuse up to 5-Helix before it can bind. As HR2 peptides are random coils (unordered) in solution, ${ }^{19,28}$ the binding step involves zipping up of the HR2 helix as well as displacement of water and any local structural rearrangments of 5-Helix. Likewise, dissociation reverses these conformational transitions before the peptide - polymer conjugate can diffuse away.

As shown in Figure 4, the interaction of 5-Helix with the HR2 peptide can thus be modeled in two steps, where the peptide first diffuses up to or away from an encounter complex (EC) before local conformational transitions take place. Rate constants $k_{1}$ and $k_{-1}$ reflect the 
diffusion step, while $k_{2}$ and $k_{-2}$ reflect the final structural rearrangements. The encounter complex reflects all possible collision orientations for the peptide and 5-Helix. Assuming the concentration of the encounter complex is low and reasonably constant, the net $k_{\text {on }}$ and $k_{\text {off }}$ is determined by the steady state-approximation:

$$
\begin{aligned}
& k_{\mathrm{on}}=\frac{k_{1} k_{2}}{k_{-1}+k_{2}} \\
& k_{\mathrm{off}}=\frac{k_{-1} k_{-2}}{k_{-1}+k_{2}}
\end{aligned}
$$

The net $k_{\text {on }}$ for unconjugated $\mathrm{C} 41$ is $2.11 \times 10^{7} \mathrm{M}^{-1} \mathrm{sec}^{-1}$, a value very close to the diffusion limit for bimolecular reactions in aqueous solution. ${ }^{37}$ The diffusion limit of the reaction modeled above is represented by $k_{-1} \ll k_{2}$ (all encounters yield productive binding) and the net association and dissociation rates can be approximated as:

$$
\begin{gathered}
k_{\mathrm{On}}=k_{1} \\
k_{\mathrm{Off}}=\frac{k_{-1} k_{-2}}{k_{2}}
\end{gathered}
$$

In this case, alterations that impact diffusion will affect both $k_{\text {on }}$ and $k_{\text {off }}$, as observed for polymer conjugation to $\mathrm{C} 41$. In contrast to the interactions of $\mathrm{C} 41$ peptides with 5-Helix, the unconjugated species studied by Plückthun and colleagues associated with substantially reduced rates $\left(<1 \times 10^{6} \mathrm{M}^{-1} \mathrm{sec}^{-1}\right)$. Such slow interactions are expected in the non-diffusion limit $k_{1} \gg k_{2}$ (the interacting species come in contact numerous times before productive binding occurs). In this limit, the net association and dissociation can be approximated as:

$$
\begin{gathered}
k_{\mathrm{on}}=\frac{k_{1} k_{2}}{k_{-1}} \\
k_{\mathrm{off}}=k_{-2}
\end{gathered}
$$

In this case, alterations that impact diffusion affect only the association rate, as reported previously. Thus, our data suggest that the impact of conjugation on both $k_{\text {on }}$ and $k_{\text {off }}$ reflects a transport limitation that only manifests when association of the unconjugated species approaches the diffusion limit. 
Binding studies between unconjugated HR2-peptides and 5-Helix reported here and elsewhere ${ }^{26,30}$ revealed picomolar/subpicomolar interaction affinities and association rates close to the diffusion limit for bimolecular reactions. It is rare (although not unprecedented) for the interaction between disordered peptides and folded proteins to achieve extremely high affinities with such rapid association kinetics. ${ }^{38}$ Since HR2-peptides adopt a random coil (unordered) conformation in the unbound state, initial encounters with gp41 HR1 regions rarely occur in orientations that mimic the final a-helical structure of the bound state. Such induced-fit reactions are expected to require multiple collisions before productive binding can occur, leading to relatively slow association. Instead, the results suggest that only a few encounters between unconjugated HR2-peptide and HR1 regions (at least in the context of 5-Helix) are sufficient to induce rapid a-helix formation leading to the bound state. Whether this highly efficient induced-fit binding occurs through electrostatic focusing, nucleation or an alternative mechanism remains to be uncovered. However, it appears to play an essential role in high potency inhibition of HIV-1 entry as unconjugated C41 is more likely to block formation of the post-fusogenic state compared to the slower peptide-polymer conjugates (Figure 5). Although further research is required to uncover how and why this phenomenon might occur, we show that the kinetic dependence to fusion inhibition is the key determinant in the production of highly potent fusion peptides.

\section{CONCLUSIONS}

This study demonstrates that polymer conjugation to a HIV-1 fusion inhibitor decreases both association and dissociation kinetics to viral gp41 with minimal disruption in equilibrium binding affinity. The altered kinetics indicate that the bulky polymer shells give rise to transport limitations to and from the viral target that exert an overall negative impact on antiviral potency. The most potent species, the unconjugated peptide, shows diffusionlimited association kinetics, implying rapid adoption of the a-helix conformation after minimal target encounters. This phenomenon is rare as binding events involving structurally disordered peptides to structurally stable proteins usually proceed slowly to accommodate required conformational changes. By contrast, association of peptide-polymer constructs does not replicate properties of diffusion-limited reactions, suggesting that polymer conjugation disrupts conformational transitions required to stabilize the bound state. Consequently, the association rate is diminished, directly contributing to the loss of antiviral potency. While peptide-polymer fusion inhibitors with enhanced pharmacokinetic properties retain antiviral activity against HIV-1, this study emphasizes that the impact of polymer conjugation on equilibrium affinity and binding kinetics must be made on a case-by-case basis to assess any disruption of inhibitory potency.

\section{EXPERIMENTAL PROCEDURES}

\section{Materials}

All Fmoc amino acids, Rink amide AM 200-400, 1-hydroxybenzotriazole $\left(\mathrm{HOBt} \cdot \mathrm{H}_{2} \mathrm{O}\right)$ and O-Benzotriazole- $N, N, N, N$-tetramethyluronium hexafluorophosphate (HBTU) were purchased and used as received from Iris Biotech GmbH (Marktredwitz, Germany). Triisopropylsilane (TIS), ethane-1,2-dithiol (EDT), trifluoroacetic acid (TFA), sodium 
trifluoroacetate (NaTFA), acryloyl chloride (99\%), diisopropylethylamine (DIEA, $98 \%$ ), dicyclohexylcarbodiimide (DCC, $99 \%$ ) cesium hydroxide monohydrate $(99.95 \%)$, ethyl vinyl ether (98\%), palladium on activated charcoal (10\% Pd), phosphate buffered saline sachets and a-cyanohydroxycinnamic acid were purchased from Sigma-Aldrich (Buchs, Switzerland). N,N-dimethylformamide was obtained from VWR, (Nyon, Switzerland) and $N$-methylpyrrolidone was obtained from Schweizerhall (Basel, Switzerland). Glycidol (96\%), ethanolamine (99\%), serinol (98\%), p-methoxybenzylalcohol (98\%), phosphorus tribromide (1.0 M solution in dichloromethane, AcroSeal®), potassium carbonate (99+\%), maleic anhydride (99\%), $\beta$-alanine (99\%), pentafluorophenol (99\%) and benzene (99\%) were obtained from Acros (Germany).

\section{Cell lines}

Human Osteogenic Skin (HOS) CCR5 cells were obtained from Dr. Nathaniel landau ${ }^{39}$ via the AIDS Research and Reference Reagent Program, Division of AIDS, NIAID, NIH. The cells were maintained in complete DMEM (+Penicillin/Streptomycin, + L-glutamine, $+10 \%$ fetal bovine serum) supplemented with puromycin. 293T cells were maintained in complete DMEM.

\section{Synthetic procedures}

\section{Synthesis of mid-functional poly(ethylene glycol)-co-(glycerol) and hyperbranched-poly(glycerol)—Ethoxy ethyl glycidyl ether (EEGE) was prepared as} described by Fitton et al., ${ }^{40}$ dried over $\mathrm{CaH}_{2}$ and freshly distilled before use. $p$ Methoxybenzylbromide was synthesized as described previously. ${ }^{41} N$-Maleoyl- $\beta$-alanine was synthesized as described previously. ${ }^{42}$ Scheme S1 and Scheme S2 represent the synthesis pathways of the mid-functional poly(ethylene glycol-co-glycerol) 3 and the hyperbranched-poly(glycerol) 4 , respectively.

$\boldsymbol{N}, \boldsymbol{N}$-Di( $p$ methoxybenzyl)aminoethanol (5)—Freshly distilled $p$-methoxybenzyl bromide ( $7.5 \mathrm{~g}, 37.5 \mathrm{mmol})$, ethanolamine $(1.15 \mathrm{~g}, 18.5 \mathrm{mmol})$ and potassium carbonate $(7$ $\mathrm{g}, 50 \mathrm{mmol}$ ) were mixed in ca. $80 \mathrm{~mL}$ of DMF and refluxed for $24 \mathrm{~h}$. After the reaction mixture was allowed to cool to room temperature, the solution was filtered and diethyl ether (ca. $200 \mathrm{~mL}$ ) was added. The organic phase was then washed with water and a saturated $\mathrm{NaHCO}_{3}$ solution and was subsequently dried over $\mathrm{MgSO}_{4}$. The filtered organic phase was dried and concentrated in vacuo to afford a highly viscous liquid. The crude product was purified by column chromatography using ethyl acetate and petroleum ether $(6: 4 \mathrm{v}: \mathrm{v})$ as eluent. Yield: $4.5 \mathrm{~g}(80 \%) .{ }^{1} \mathrm{H}-\mathrm{NMR}(300 \mathrm{MHz}, \mathrm{DMSO}): \delta(\mathrm{ppm})=7.26-6.85(8 \mathrm{H}$, aromatic), 4.33 (t, J= $6 \mathrm{~Hz} 1 \mathrm{H}, \mathrm{OH}), 3.72\left(\mathrm{~s}, 6 \mathrm{H}, \mathrm{OCH}_{3}\right), 3.47\left(\mathrm{~s}, 4 \mathrm{H}, \mathrm{NCH}_{2} \mathrm{Ph}\right), 3.44(\mathrm{t}, \mathrm{J}=$ $\left.6 \mathrm{~Hz}, 2 \mathrm{H}, \mathrm{CH}_{2} \mathrm{OH}\right), 2.65\left(\mathrm{t}, \mathrm{J}=6 \mathrm{~Hz}, 2 \mathrm{H}, \mathrm{NCH}_{2}\right)$. ESI-MS: $302.5\left(\mathrm{M}+\mathrm{H}^{+}\right), 324.8\left(\mathrm{M}+\mathrm{Na}^{+}\right)$.

$\boldsymbol{N}, \boldsymbol{N}$-Di(p-methoxybenzyl)serinol (6)—was synthesized as above and as described ${ }^{43}$ with the following ratios: serinol ( $1.13 \mathrm{~g}, 12.4 \mathrm{mmol}), p$-methoxybenzyl bromide (5.03 g, 25 mmol), potassium carbonate $(4.8 \mathrm{~g}, 35 \mathrm{mmol}), 80 \mathrm{~mL}$ DMF. Yield: $(3.1 \mathrm{~g}, 78 \%) .{ }^{1} \mathrm{H}-\mathrm{NMR}$ (300 MHz, DMSO-d6): $\delta$ (ppm): 7.23-6.84 (8H, aromatic), 4.28 (br, 2H, OH), 3.70 (s, 6H, $\left.\mathrm{OCH}_{3}\right), 3.62\left(\mathrm{~s}, 4 \mathrm{H}, \mathrm{NCH}_{2} \mathrm{Ph}\right), 3.54\left(\mathrm{~m}, 2 \mathrm{H}, \mathrm{CH}_{2} \mathrm{OH}\right), 2.66(\mathrm{t}, \mathrm{J}=6 \mathrm{~Hz}, 1 \mathrm{H}, \mathrm{NCH})$. ESIMS: $322.8\left(\mathrm{M}+\mathrm{H}^{+}\right)$. 
Polymerization (general procedure)—The respective initiator 5 or 6 (ca. $100 \mathrm{mg}$ ) was placed in a Schlenk flask and dissolved in benzene (ca. $5 \mathrm{~mL}$ ) under an Argon atmosphere. Cesium hydroxide monohydrate was introduced to achieve a degree of deprotonation of $50 \%$. The mixture was stirred at $60{ }^{\circ} \mathrm{C}$ over a period of $45 \mathrm{~min}$ and then heated to $80-$ $90{ }^{\circ} \mathrm{C}$ in vacuo for 2 hours to remove the formed water and benzene azeotropically. In a separate setup firstly dry THF and the respective monomers (ethylene oxide or EEGE, predried over $\mathrm{CaH}_{2}$ ) were distilled into a Schlenk flask equipped with a stir bar, a Teflon tap and a rubber septum. The flask was closed under vacuum and the cesium salt of the initiator was added dissolved in dry DMSO (the final concentration was approx. $10 \mathrm{wt} \%$ of the monomer in a 9:1 mixture of THF and DMSO). The reaction mixture was directly heated to $70{ }^{\circ} \mathrm{C}$ in static vacuo over a period of $20 \mathrm{~h}$ and quenched by the addition of methanol and acidic ion exchange resin. The solution was filtered, concentrated and precipitated into diethyl ether / acetone (70:30) first and subsequently in pure diethyl ether to yield the final polymer hyperbranched and mid-functional polymer precursors, respectively after drying in a yield typically between $90 \%$ to quantitative. ${ }^{1} \mathrm{H}-\mathrm{NMR}$ (DMSO- $d_{6}, 300 \mathrm{MHz}$ ): $7.22-6.82$ (dd, $8 \mathrm{H}$, aromatic signals from the initiator), $4.64(\mathrm{br} \mathrm{s}$, acetal $\mathrm{H}), 3.69\left(\mathrm{~s}, 6 \mathrm{H}, \mathrm{MeO}-\mathrm{C}_{6} \mathrm{H}_{4}-\right.$ ), 3.64-3.18 (br, $-\mathrm{CH}_{2}-\mathrm{CH}_{(2)} \mathrm{O}$ - (backbone), and - $\mathrm{O}-\mathrm{CH}_{2}-\mathrm{CH}_{3}$ (side chain)), 1.25-0.9 (-O$\mathrm{CH}_{2}-\mathrm{CH}_{3}$ and $\left.-\mathrm{CH}-\mathrm{CH}_{3}\right)$. The degree of branching was determined by NMR as described by Wurm et al. ${ }^{44}$

Removal of the acetal protective groups-The acetal-protected copolymer was dissolved in methanol (ca. $20 \mathrm{wt} \%$ ) and diluted with the same volume of $1 \mathrm{~N} \mathrm{HCl}$. The mixture was stirred at room temperature overnight, concentrated in vacuo and precipitated three times into diethyl ether to yield $\mathbf{7 a}$ and $\mathbf{7 b}$. The isolated yields ranged between $80-$ $90 \% .{ }^{1} \mathrm{H}-\mathrm{NMR}$ (DMSO- $d_{6}, 300 \mathrm{MHz}$ ): $10.57\left(\mathrm{H}^{-\mathrm{N}^{+}} \mathrm{R}_{3}, 1 \mathrm{H}\right), 7.54-6.97$ (dd, 8H, aromatic signals from the initiator), 4.27 (br s, $\mathrm{OH}$, intensity and position can vary), 3.75 (s, $6 \mathrm{H}$, $\left.\mathrm{MeO}-\mathrm{C}_{6} \mathrm{H}_{4}-\right)$, 3.64-3.18 (br, $-\mathrm{CH}_{2}-\mathrm{CH}_{(2)} \mathrm{O}-($ backbone)).

Hypergrafting / Slow monomer addition-The linear precursor polymer 7a was dissolved (or suspended) in benzene at a concentration of ca. $20 \mathrm{wt} \%$. Cesium hydroxide monohydrate was added (to achieve a degree of deprotonation of $20 \%$ ) and the mixture was allowed to react at $60{ }^{\circ} \mathrm{C}$ for $60 \mathrm{~min}$. The formed water and benzene were removed azeotropically at $90{ }^{\circ} \mathrm{C}$ over a period of $90 \mathrm{~min}$. The activated macroinitiator was suspended in dry diglyme (ca. $20 \mathrm{wt} \%$ ), heated to $90{ }^{\circ} \mathrm{C}$, and freshly distilled glycidol in dry diglyme (ca. $20 \mathrm{wt} \%$ ) was added slowly with a syringe pump over a period of $4-5$ hours. The reaction was stopped by the addition of methanol and acidic ion exchange resin, filtered, concentrated in vacuo and precipitated into diethyl ether. Yield: quantitative.

Hydrogenation (general procedure)-Hyperbranched polymer or mid-functional polymer (ca. $1 \mathrm{~g}$ ) was dissolved in the hydrogenation vessel in degassed methanol and palladium on activated charcoal (ca. 100-200 mg) was added under a stream of argon. The vessel was closed, pressurized with hydrogen ( 8 bar) and stirred at room temperature until no residual aromatic signals could be detected by ${ }^{1} \mathrm{H}-\mathrm{NMR}$ spectroscopy to yield $\mathbf{8}$ or $\mathbf{1 0}$, respectively. Typically $24-48$ hours was necessary to achieve complete conversion. ${ }^{1} \mathrm{H}-\mathrm{NMR}$ 
(DMSO- $d_{6}, 300 \mathrm{MHz}$ ): 5.0-3.80 (br, OH, intensity and position can vary), 3.64-3.10 (br, $\mathrm{CH}_{2}-\mathrm{CH}_{(2)} \mathrm{O}-$ (backbone)).

Synthesis of the 3-(maleimido)propionic acid pentafluorophenyl ester (9)- $\mathrm{N}$ Maleoyl- $\beta$-alanine $1 \mathrm{~g}(5.9 \mathrm{mmol})$ and pentafluorophenol ( $1.1 \mathrm{~g}, 6 \mathrm{mmol}, 1.02$ equiv) were dissolved in dry DMF $(15 \mathrm{~mL})$ and cooled with an ice-bath. To this mixture were added DMAP $(10 \mathrm{mg})$ and dicyclohexylcarbodiimide $(1.29 \mathrm{~g}, 6.25 \mathrm{mmol}, 1.06$ equiv). The reaction was stirred at $4{ }^{\circ} \mathrm{C}$ for $2 \mathrm{~h}$ and left to warm up to room temperature overnight. The mixture was cooled with an ice bath and stirred an additional hour to induce precipitation of the dicyclohexylurea, which was filtered off. The filtrate was dried under vacuum and purified via silica chromatography with dichloromethane as an eluent. Yield $85 \%(1.7 \mathrm{~g}$, white powder). ${ }^{1} \mathrm{H}-\mathrm{NMR}$ (DMSO- $\left.d_{6}, 300 \mathrm{MHz}\right): 7.00(2 \mathrm{H}, \mathrm{s}, \mathrm{HC}=\mathrm{CH}), 3.95\left(2 \mathrm{H}, \mathrm{t}, \mathrm{CH}_{2}\right), 2.95$ $\left(2 \mathrm{H}, \mathrm{t}, \mathrm{CH}_{2}\right) \cdot{ }^{13} \mathrm{C}-\mathrm{NMR}$ (DMSO- $\left.d_{6}, 75 \mathrm{MHz}\right): 170.7$ (O=C-N-C=O), 167.3 (COOPFP), 142.9-135.9 (aromic carbons, weak signals), $134.7(\mathrm{C}=\mathrm{C}), 32.9\left(\mathrm{CH}_{2}\right), 31.4\left(\mathrm{CH}_{2}\right)$.

\section{Synthesis of maleimido-modified midfunctional poly(EG)-co-(G) and hyperbranched PG-3-(maleimido)propionic acid pentafluorophenyl ester (9) was} reacted with the polymers $\mathbf{1 0}$ and $\mathbf{8}$ to yield maleimido functionalized polymers $\mathbf{4}$ (Scheme S1) and $\mathbf{3}$ (Scheme S2), respectively. In brief, the polymer was dissolved in methanol (ca. 20 wt \%) and a two-molar excess of $\mathbf{9}$ was added at room temperature. The reaction was initiated by the addition of $100 \mu \mathrm{L}$ triethylamine and allowed to proceed for $8 \mathrm{~h}$. The mixture was concentrated at reduced pressure and precipitated three times into cold diethyl ether. Yields typically $90-95 \%$. The final ${ }^{1} \mathrm{H}-\mathrm{NMR}$ for maleimido-modified midfunctional p(EG-co-G) 3 and maleimido-modified hbPG 4 are shown in Figure S1 and S2, respectively. Figure S4 shows the GPC elugram of the maleimido-modified midfunctional p(EG-co-G) 3 and maleimido-modified hbPG 4.

\section{Synthesis of acrylate end-group modified PEG750 and PEG2000-}

Monomethoxy-PEG750-OH (mPEG-OH, $5.0 \mathrm{~g}, 6.7 \mathrm{mmol}$ ) was dried azeotropically in 50 $\mathrm{mL}$ dry toluene through rotary evaporation. The remaining $\mathrm{mPEG}-\mathrm{OH}$ melt was placed on ice and dissolved in $300 \mathrm{~mL}$ dry DCM. After addition of $\mathrm{Et}_{3} \mathrm{~N}$ (1.86 mL, 2.0 equiv), acryloyl chloride $(0.81 \mathrm{~mL}, 1.5$ equiv) was added dropwise for 30 minutes. The reaction proceeded with stirring overnight in the dark at room temperature under nitrogen. The resulting pale yellow solution was extracted twice with $5 \% \mathrm{HCl}$, twice against $5 \% \mathrm{NaOH}$, once against saturated $\mathrm{NaHCO}_{3}$ and once against brine. The DCM layer was collected and dried over $\mathrm{MgSO}_{4}$ and the volume of the solution was reduced to approximately $5 \mathrm{~mL}$ using rotary evaporation. Precipitation of $\mathrm{mPEG}$ was induced by addition of $\mathrm{Et}_{2} \mathrm{O}(80 \mathrm{~mL})$ and overnight storage at $-20^{\circ} \mathrm{C}$. The white precipitate was dried in vacuo. Yield: $42 \%$; conversion $\mathrm{OH}$ to acrylate: $95 \%$ (from ${ }^{1} \mathrm{H}-\mathrm{NMR}$ analysis). ${ }^{1} \mathrm{H}-\mathrm{NMR}\left(\mathrm{CDCl}_{3}, 400 \mathrm{MHz}\right.$ ): $3.3 \mathrm{ppm}(\mathrm{s}, 3 \mathrm{H}$, methoxy), $3.6 \mathrm{ppm}$ (m, 68H, PEG chain protons), $4.3 \mathrm{ppm}\left(\mathrm{t}, 2 \mathrm{H}, \mathrm{CH}_{2} \mathrm{CHOOCH}_{2} \mathrm{CH}_{2}\right.$-PEG chain), 5.8 and 6.4 (dd, $1 \mathrm{H}, \mathrm{CH}_{2} \mathrm{CHOOCH}_{2} \mathrm{CH}_{2}$-PEG chain), 6.1 (dd, $1 \mathrm{H}$, $\mathrm{CH}_{2} \mathrm{CHOOCH} \mathrm{CH}_{2}$-PEG chain). MALDI-TOF MS confirmed the molar mass. $\left(\left[\mathrm{M}(\mathrm{n}=16)+\mathrm{Na}^{+}\right]=812.4 \mathrm{~g} / \mathrm{mol}\right)$. See Figure S3a for NMR spectrum.

Monomethoxy PEG2000-acrylate was prepared from mPEG2000-OH using the same reaction conditions used to obtain PEG750-acrylate (5.0 g, $2.5 \mathrm{mmol})$. Yield: 77\%; 
conversion $\mathrm{OH}$ to acrylate: $95 \%$ (from ${ }^{1} \mathrm{H}$ NMR analysis). ${ }^{1} \mathrm{H}$ NMR $\left(\mathrm{CDCl}_{3}, 400 \mathrm{MHz}\right): 3.3$ ppm (s, 3H, methoxy), $3.6 \mathrm{ppm}$ (m, 180H, PEG chain protons), $4.3 \mathrm{ppm}(\mathrm{t}, 2 \mathrm{H}$, $\mathrm{CH}_{2} \mathrm{CHOOCH}_{2} \mathrm{CH}_{2}$-PEG chain), 5.8 and 6.4 (dd, $1 \mathrm{H}, \mathrm{CH}_{2} \mathrm{CHOOCH}_{2} \mathrm{CH}_{2}-\mathrm{PEG}$ chain), 6.1 (dd, $1 \mathrm{H}, \mathrm{CH}_{2} \mathrm{CHOOCH} \mathrm{CH}_{2}$-PEG chain). MALDI-TOF MS confirmed the molar mass. $\left(\left[M(n=44)+\mathrm{Na}^{+}\right]=2046.5 \mathrm{~g} / \mathrm{mol}\right)$. See Figure $\mathrm{S} 3 \mathrm{~b}$ for NMR spectrum. MALDI-TOF spectra of the monomethoxy-PEG750, monomethoxy-PEG2000, monomethoxy PEG750-acrylate and monomethoxy PEG2000-acrylate has been reported in a previous study. ${ }^{19}$ Figure S4 shows the GPC elugram of the PEG acrylates.

Peptide synthesis-All peptides were synthesized using a CEM Liberty® Microwaveassisted solid phase peptide synthesizer at $0.25 \mathrm{mmol}$ scale. Protected unmodified and cysteine containing peptides were synthesized on a Rink amide AM resin (200-400 mesh, $0.71 \mathrm{mmol} / \mathrm{g}$ loading). A cycle for amino acid coupling consists of an Fmoc deprotection step, resin washing steps, amino acid coupling step followed by washing steps. The Fmoc group was removed in two stages. First, $20 \%$ piperidine $(5 \mathrm{~mL})$ containing $0.1 \mathrm{M}$ $\mathrm{HOBT} \cdot \mathrm{H}_{2} \mathrm{O}$ irradiated by $54 \mathrm{~W}$ microwave power for 30 seconds. This deprotection solution was then removed and a second addition of $20 \%$ piperidine $(5 \mathrm{~mL})$ containing $0.1 \mathrm{M}$ $\mathrm{HOBT} \cdot \mathrm{H}_{2} \mathrm{O}$ was added to the resin, which was subsequently irradiated for 7 minutes with 54 W microwave power. After washing the resin 5-fold with $10 \mathrm{~mL}$ DMF, the Fmoc protected amino acid $(0.2 \mathrm{M})$ is added along with the activator $2 \mathrm{~mL} \mathrm{HOBT} \cdot \mathrm{H}_{2} \mathrm{O}(0.5 \mathrm{M})$ and $1 \mathrm{~mL}$ DIEA ( $2 \mathrm{M}$ ) yielding the mole ratio of $1: 2: 1$ for activator, base, amino acid, respectively. The coupling reaction of the Fmoc-amino acid was achieved with $24 \mathrm{~W}$ microwave power. After completion of the synthesis, the peptide is cleaved from the resin and deprotected using $10 \mathrm{~mL}$ of a mixture of trifluoroacetic acid (TFA), triisopropylsilane (TIS), ethane-1,2dithiol (EDT) and MilliQ water ( $\sim 18 \mathrm{M} \Omega \mathrm{cm}$, Millipore) in the volume ratio $92.5: 2.5: 2.5$ : $2.5 \%$ for $3.5-4$ hours at room temperature. The crude peptide was precipitated and washed with cold diethyl ether. The crude peptide was then dissolved in MilliQ water and freeze dried prior to purification by preparative reverse phase HPLC.

Peptide purification-All peptides were purified by preparative high pressure liquid chromatography (HPLC) using a Waters 600 automated gradient controller pump module connected to a Waters prep degasser system. The elution of the peptides was monitored by using a Waters 2487 dual $\lambda$ absorbance detector and collected using a Waters fraction collector III. Purification of all peptides was achieved using an Atlantis ${ }^{\circledR} \mathrm{OBD}^{\mathrm{TM}} \mathrm{C}-18$ reverse phase column (Waters) equilibrated with a water / TFA (0.1\% TFA in water, Solvent A) and acetonitrile/TFA ( $0.1 \%$ TFA in acetonitrile, Solvent B). Elution was achieved at 20 $\mathrm{mL} / \mathrm{min}$ by typically running gradients of 40 to $50 \%$ solvent B over 20 minutes. All peptides were purified to $95 \%$ by preparative HPLC and verified for purity by analytical HPLC using a monomeric C-18 column (S/N E950404-10-3, Vydac). Fractions containing peptide were detected by UV absorbance at 220 and $280 \mathrm{~nm}$. The molecular masses of the peptides were verified by electrospray ionization mass spectrometry (ESI-MS) or MALDITOF MS using a-cyanohydroxycinnamic acid as the matrix as described the Supporting Information. The molecular masses of all peptides were within the error margin of $1 \mathrm{Da}$ (Figure S5). All verified peptide samples were freeze-dried yielding a white powder. 


\section{Polymer conjugation to peptides and purification of peptide-polymer} conjugates-PEG750-acrylate and PEG2000-acrylate was attached to cysteine-modified peptides as described previously. ${ }^{19}$ A conjugation experiment was performed with cysteinemodified peptide ( $\sim 8 \mathrm{mg}, 16 \mu \mathrm{mol})$ and PEG-acrylate ( $400 \mu \mathrm{mol}, 25$ equiv.) in $10 \mathrm{mM}$ phosphate buffer $\mathrm{pH}$ 7.4. The reaction was allowed to stir for $44-48$ hours at room temperature followed by purification by reverse phase HPLC achieved with a C18 column. The peptide-mPEG750 and the peptide-mPEG2000 reaction mixtures were analyzed and the products were isolated with preparative RP-HPLC using a gradient of $40-50 \%$ of acetonitrile (solvent B) in 20 minutes. The conjugate fractions were freeze dried and lyophilized to yield a white powder. MALDI-TOF MS confirmed the molar mass of the repeat unit $(44.05 \mathrm{~g} / \mathrm{mol})$ and a mass distribution corresponding to the peptide - PEG with a defined number of repeat units.

The synthesis of the mid-functional $\mathrm{P}(\mathrm{EG}-\mathrm{co}-\mathrm{G})$ and $\mathrm{hbPG}$ - peptide conjugates were made by dissolving maleimide-modified mid-functional $\mathrm{P}(\mathrm{EG}-\mathrm{co}-\mathrm{G})$ and maleimide-modifiedhbPG in $0.5 \mathrm{~mL}$ DMSO to yield a stock concentration of $10 \mathrm{mg} / \mathrm{mL}(2.5 \mu \mathrm{mol})$ followed by

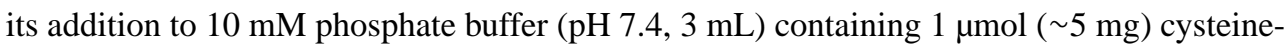
modified peptide. The mixture was stirred for 1 hour at room temperature. The reaction mixture was then dialyzed for 24 hours against $10 \mathrm{mM}$ phosphate buffered saline, $\mathrm{pH} 7.4$ using regenerated cellulose membrane (MWCO 3000). The conjugates were purified using reverse phase HPLC achieved with a C18 column using a gradient of 40-50\% acetonitrile (solvent B) in 20 minutes. The conjugate fractions were collected and freeze-dried to yield off-white peptide-polymer conjugates. The mass range of peptide-mid-functional P(EG-coG) and peptide-hbPG conjugates were verified with MALDI-TOF, however due to the poor ionization of the peptide-mid-functional $\mathrm{P}(\mathrm{EG}-c o-\mathrm{G})$ and peptide-hbPG conjugates only low-resolution spectra were obtained confirming range of masses. See Figures S1 - S3 for ${ }^{1} \mathrm{H}-\mathrm{NMR}$ of final acrylate- or maleimide -modified polymers and Figures S6 - S8 for analytical reverse phase HPLC chromatograms and MALDI-TOF mass spectra of the conjugates.

Stock concentrations of all peptide and peptide-polymer conjugates were prepared in TRIS buffer $\mathrm{pH} 8.0$ and the concentration determined by absorbance at $280 \mathrm{~nm}$ using the method of Pace et al. ${ }^{45}$; the molar extinction coefficient was $17990 \mathrm{M}^{-1} \cdot \mathrm{cm}^{-1}$ for all peptides and peptide-polymer conjugates in this manuscript.

\section{Biochemistry and virology}

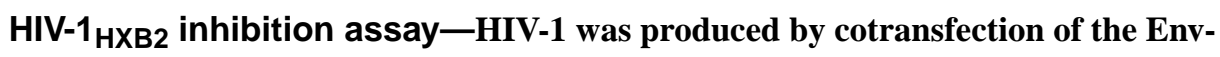
deficient HIV-1 genome (pNL4-3 $\mathrm{R}^{-} \mathrm{E}^{-} \mathrm{Luc}^{+}$) and the $\mathrm{Env}_{\mathrm{HXB}}{ }^{-}$expression plasmid (pEBB_Env ${ }_{\mathrm{HXB}}$ ) into $293 \mathrm{~T}$ cells (Lipofectamine Plus, Invitrogen) as previously described. ${ }^{39,46,47} \mathrm{HIV}-1_{\mathrm{HXB} 2}$ pseudoviruses harvested 48 hours post-transfection were either frozen $\left(-80^{\circ} \mathrm{C}\right)$ for later use or applied directly to HOS CCR5 target cells. HOS CCR5 cells, which contain $\sim 5 \times 10^{3} \mathrm{CXCR} 4$ per cell, were plated at 50,000 cells $/ \mathrm{mL}$ in 48 -well plates and incubated overnight at $37^{\circ} \mathrm{C}, 5 \% \mathrm{CO}_{2}$, prior to infection. On the day of infection, media was aspirated and replaced with $100 \mu \mathrm{L}$ complete DMEN in the presence or absence of inhibitor (at $2 \mathrm{x}$ concentration up to $2 \mu \mathrm{M}$ ) and, subsequently, an additional $100 \mu \mathrm{L}$ of harvested 
$\mathrm{HIV}-1_{\mathrm{HXB} 2}$-containing supernatant. Infections were incubated for 48 hours at $37^{\circ} \mathrm{C}, 5 \% \mathrm{CO}_{2}$; the cultures were supplemented with an additional $500 \mu \mathrm{L}$ of complete DMEN after 24 hours. At termination, cultures were aspirated and cells were lysed with $100 \mu \mathrm{L}$ of $1 \%$ triton$\mathrm{X}$ in $25 \mathrm{mM}$ TRIS buffer pH 8.0, 1 mM EGTA, $1 \mathrm{mM}$ DTT, $10 \%$ glycerol. HIV-1 $1_{\mathrm{HXB} 2}$ infection was quantified by expression of a luciferase-reporter construct (Luciferase Assay System, Promega) monitored using a FLUOStar Optima luminometer (BMG LABTECH, Offenburg, Germany). The fraction HIV-1 infectivity in each well was determined based on the relative signals obtained from unhibited and fully inhibited control wells (no inhibitor or $1 \mu \mathrm{M}$ C-peptide $\mathrm{C} 37,{ }^{26}$ respectively). Inhibition data were fit to a Langmuir equation to obtain $\mathrm{IC}_{50}$ values (Origin Software).

Production of fluorescein modified 5-Helix-5-Helix is a $25 \mathrm{kDa}$ His-tagged protein consisting of three HR1 $\left(\operatorname{Env}_{\mathrm{HXB} 2}\right.$ residues $\left.542-581\right)$ and two HR2 domains $\left(\operatorname{Env}_{\mathrm{HXB}} 2\right.$ residues 625 - 662) alternately connected through Gly/Ser linkers. A 5-Helix variant with a C-terminal Cys residue ${ }^{26}$ was recombinantly expressed in E. coli and solubilized from bacterial inclusion bodies using $8 \mathrm{M}$ guanidine hydrochloride in TRIS buffered saline (TBS). The unfolded 5-Helix protein was isolated on a Ni-NTA agarose column and fluorescein was conjugated to the C-terminal Cys residue using fluorescein-maleimide (Molecular Probes). Labeled protein was refolded on the beads by gradual reduction of guanidine concentration ( 8 to $1 \mathrm{M}$ in 20 column volumes) and then eluted in $250 \mathrm{mM}$ imidazole in TBS.

Fluorescein-5-Helix was purified from aggregates on a Sephacryl S200 HR column (GE) and the concentration determined by the method of Edelhoch correcting for the absorption of fluorescein at $280 \mathrm{~nm} .{ }^{48}$ Concentrations were confirmed by stoichiometric titrations with C37 peptide using the KinExA 3000 flow fluorimeter (see below).

Production of C37 for affinity and kinetics experiments-The His-tagged C37 peptide derived from $\mathrm{HIV}-1_{\mathrm{HXB} 2}$ Env residues $625-661$ was produced via a recombinant expression of the trimer-of-hairpins construct $\mathrm{NC} 1$ in E. coli. ${ }^{26,28} \mathrm{NC} 1$ was isolated from bacterial lysate using a Ni-NTA agarose and then subject to trypsin digestion (1:250 mass ratio, $4^{\circ} \mathrm{C}$ overnight) to cleave $\mathrm{C} 37$ from the HR1 domain. The resulting $\mathrm{C} 37$ was purified to homogeneity by reverse phase HPLC using a water/acetonitrile gradient containing $0.1 \%$ trifluoroacetic acid. The identity of C37 peptide was confirmed by mass spectrometry.

Binding measurements-Equilibrium dissociation constants $\left(K_{\mathrm{D}}\right.$ values) reflecting solution-phase interactions between peptide (or peptide-polymer) and fluorescein-5-Helix (5H-f) were obtained using a KinExA 3000 flow fluorometer (Sapidyne Instruments). ${ }^{26}$ Briefly, C-peptide-conjugated beads were prepared by incubating $100 \mathrm{mg}$ azlactone (Pierce) with $200 \mu \mathrm{g} \mathrm{C} 37 \mathrm{in} 1 \mathrm{~mL}$ sodium carbonate $(50 \mathrm{mM}, \mathrm{pH} 9.5)$ at room temperature for 1 hour followed by $4{ }^{\circ} \mathrm{C}$ overnight. Remaining binding sites were subsequently blocked by the addition of bovine serum albumin (BSA, Sigma-Aldrich) to a final concentration of 1 $\mathrm{mg} / \mathrm{mL}$ and incubating at room temperature for 1 hour. Blocked C37-conjugated beads (50 $\mathrm{mg}$ ) were diluted into TBS supplemented with $0.02 \%$ sodium azide $(35 \mathrm{~mL})$ for instrument use. Binding samples were prepared by mixing a constant amount of $5 \mathrm{H}-\mathrm{f}$ ( 200 to $500 \mathrm{pM}$ ) with increasing concentrations of peptide-polymer (0 to $50 \mathrm{nM}$ ) in TBS supplemented with $100 \mu \mathrm{g} / \mathrm{ml} \mathrm{BSA,} 0.02 \%$ sodium azide and $1 \mathrm{mM}$ phenylmethylsulfonyl fluoride. Samples 
were incubated 3 hours at room temperature (empirically determined to be sufficient for the binding reactions to reach equilibria).

At the time of measurment, the instrument loaded a small amount of beads $(\sim 5 \mu \mathrm{L})$ into a fluorescent flow cell and then passed a single sample through it. Since C41 and C37 compete for the same binding site on 5-Helix, the change in bead fluorescence due to $5 \mathrm{H}-\mathrm{f}$ binding was directly proportional to the free (unbound) concentration of $5 \mathrm{H}-\mathrm{f}$ in solution. Measured fluorescence signals, obtained in duplicate, were normalized to maximum and minimum signals obtained from samples lacking peptide or containing $10 \mathrm{nM} \mathrm{C} 37\left(K_{\mathrm{D}}=\right.$ $0.65 \mathrm{pM})$, respectively. $K_{\mathrm{D}}$ values for each interaction were determined by fitting fluorescence data for each titration to a general model of equilibrium bimolecular binding using the manufacturer's software. ${ }^{30}$ The affinity data presented in Table 2 represent the mean and standard error of measurement from three or more independent experiments. The set up of the affinity experiment is illustrated in Figure S10 and the results of the affinity measurements are presented in Figure S14 - S17. A comparison of the equilibrium affinity results is presented in Figure 3.

Solution phase binding kinetics were measured as described above for affinity measurements, except that the peptide-polymers were mixed with $5 \mathrm{H}-\mathrm{f}$ on the instrument for 7.2 seconds before being passed over $\mathrm{C} 37$-conjugated beads. ${ }^{26}$ Association rate constants $\left(k_{\text {on }}\right)$ were determined by fitting the fluorescent data to a general model of nonequilibrium bimolecular interactions. The values reported in Table 2 represent the mean and standard error of measurement of three independent experiments for each peptide polymer. A comparison of the kinetic measurements is presented in Figure S11 and Figure S12. Values for $k_{\text {off }}$ were determined as described in the text; details of the propagation of errors calculation for $k_{\text {off }}$ is described in the Supporting Information.

\section{Supplementary Material}

Refer to Web version on PubMed Central for supplementary material.

\section{Acknowledgments}

This work was supported within the European Union's framework programme 6 (FP6) 'NanoBioPharmaceutics' (NMP4-CT-2006-026723 to H.-A.K.) The European Science Foundation Precision Polymer Materials (P2M) Research Networking Programme, the NCCR Nanoscale Science as well as the Alexander von Humboldt-Stiftung for a Feodor-Lynen fellowship to F.R.W. The work was also supported by the NIH through grant R01 GM066682 to M.J.R. Binding measurements were performed in the X-ray Crystallography and Molecular Interactions Facility of the Sidney Kimmel Cancer Center at Thomas Jefferson University (CA56036).

\section{ABBREVIATIONS}

$\begin{array}{ll}\text { CCR5 } & \text { CC chemokine receptor 5 } \\ \text { CXCR4 } & \text { C-X-C chemokine receptor 4 } \\ \text { hbPG } & \text { hyperbranched poly(glycerol) } \\ \text { gp41 } & \text { glycoprotein } 41\end{array}$




$\begin{array}{ll}\text { HIV-1 } & \text { human immunodefiency virus type 1 } \\ \text { HR1 } & \text { heptad repeat 1 } \\ \text { HR2 } & \text { heptad repeat 2 } \\ \text { HOS } & \text { Human Osteosarcoma } \\ \text { PEG } & \text { poly(ethylene glycol) } \\ \text { p(EG-co-G) copolymer } & \text { poly(ethylene glycol-co-glycerol) } \\ \text { BSA } & \text { bovine serum albumin }\end{array}$

\section{REFERENCES}

1. Leader B, Baca QJ, Golan DE. Protein therapeutics: A summary and pharmacological classification. Nat. Rev. Drug Discovery. 2008; 7:21-39. [PubMed: 18097458]

2. Veronese FM, Caliceti P, Schiavon O. Branched and linear poly(ethylene glycol): Influence of the polymer structure on enzymological, pharmacokinetic, and immunological properties of protein conjugates. J. Bioact. Compat. Polym. 1997; 12:196-207.

3. Veronese FM. Peptide and protein PEGylation: A review of problems and solutions. Biomaterials. 2001; 22:405-417. [PubMed: 11214751]

4. Yamaoka T, Tabata Y, Ikada Y. Distribution and tissue uptake of poly(ethylene glycol) with different molecular weights after intravenous administration to mice. J. Pharm. Sci. 1994; 83:601-606. [PubMed: 8046623]

5. Vandegriff KD, McCarthy M, Rohlfs RJ, Winslow RM. Colloid osmotic properties of modified hemoglobins: Chemically cross-linked versus polyethylene glycol surface-conjugated. Biophys. Chem. 1997; 69:23-30. [PubMed: 9440206]

6. Monfardini C, Schiavon O, Caliceti P, Morpurgo M, Harris JM, Veronese FM. A branched monomethoxypoly(ethylene glycol) for protein modification. Bioconjugate Chem. 1995; 6:62-69.

7. Jiang S, Lin K, Strick N, Neurath AR. HIV-1 inhibition by a peptide. Nature. 1993; 365:113. [PubMed: 8371754]

8. Wild C, Greenwell T, Matthews T. A synthetic peptide from HIV-1 gp41 is a potent inhibitor of virus-mediated cell-cell fusion. AIDS Res. Hum. Retroviruses. 1993; 9:1051-1053. [PubMed: 8312047]

9. Bianchi E, Finotto M, Ingallinella P, Hrin R, Carella AV, Hou XS, Schleif WA, Miller MD, Geleziunas R, Pessi A. Covalent stabilization of coiled coils of the HIV gp41 N region yields extremely potent and broad inhibitors of viral infection. Proc. Natl. Acad. Sci. U. S. A. 2005; 102:12903-12908. [PubMed: 16129831]

10. Eggink D, Berkhout B, Sanders RW. Inhibition of HIV-1 by fusion inhibitors. Curr. Pharm. Des. 2010; 16:3716-3728. [PubMed: 21128887]

11. Mehellou Y, De Clercq E. Twenty-six years of anti-HIV drug discovery: Where do we stand and where do we go? J. Med. Chem. 2010; 53:521-538. [PubMed: 19785437]

12. Danial M, Klok H-A. Polymeric Anti-HIV Therapeutics. Macromol. Biosci. 2015; 15:9-35. [PubMed: 25185484]

13. Fuzeon Product Information. [accessed July 2016] http://www.rocheusa.com/products/fuzeon/ pi.pdf

14. Volberding PA, Deeks SG. Antiretroviral therapy and management of HIV infection. Lancet. 2010; 376:49-62. [PubMed: 20609987]

15. Wei X, Decker JM, Liu H, Zhang Z, Arani RB, Kilby JM, Saag MS, Wu X, Shaw GM, Kappes JC. Emergence of resistant human immunodeficiency virus type 1 in patients receiving fusion inhibitor (T-20) monotherapy. Antimicrob. Agents Chemother. 2002; 46:1896-1905. [PubMed: 12019106]

16. Bailon, PS., Won, C-Y. US 2006/7084261. 2006. 
17. Bailon, PS., Won, C-Y. US 2006/7049415. 2006.

18. Cheng S, Wang Y, Zhang Z, Lv X, Gao GF, Shao Y, Ma L, Li X. Enfuvirtide-PEG conjugate: A potent HIV fusion inhibitor with improved pharmacokinetic properties. Eur. J. Med. Chem. 2016; 121:232-237. [PubMed: 27240277]

19. Danial M, Van Dulmen THH, Aleksandrowicz J, Pötgens AJG, Klok H-A. Site-specific PEGylation of HR2 peptides: Effects of PEG conjugation position and chain length on HIV-1 membrane fusion inhibition and proteolytic degradation. Bioconjugate Chem. 2012; 23:16481660.

20. Danial M, Klok H-A. Combating HIV-1 Entry and Fusion with Peptide -Synthetic Polymer Conjugates. ACS Symp. Ser. 2013; 1135:105-125.

21. Siegers C, Biesalski M, Haag R. Self-Assembled Monolayers of Dendritic Polyglycerol Derivatives on Gold That Resist the Adsorption of Proteins. Chem.-Eur. J. 2004; 10:2831-2838. [PubMed: 15195314]

22. Kainthan RK, Brooks DE. In vivo biological evaluation of high molecular weight hyperbranched polyglycerols. Biomaterials. 2007; 28:4779-4787. [PubMed: 17706767]

23. Wilms D, Salah-Eddine S, Frey H. Hyperbranched polyglycerols: From the controlled synthesis of biocompatible polyether polyols to multipurpose applications. Acc. Chem. Res. 2010; 43:129-141. [PubMed: 19785402]

24. Weissenhorn W, Dessen A, Harrison SC, Skehel JJ, Wiley DC. Atomic structure of the ectodomain from HIV-1 gp41. Nature. 1997; 387:426-430. [PubMed: 9163431]

25. Chan DC, Chutkowski CT, Kim PS. Evidence that a prominent cavity in the coiled coil of HIV type 1 gp41 is an attractive drug target. Proc. Natl. Acad. Sci. U. S. A. 1998; 95:15613-15617. [PubMed: 9861018]

26. Kahle KM, Steger HK, Root MJ. Asymmetric deactivation of HIV-1 gp41 following fusion inhibitor binding. PLoS Pathog. 2009; 5:e1000674. [PubMed: 19956769]

27. Bray, B., Myung-Chol, K., Tvermoes, N., Kinder, DWLJ. US 2004/029073 A2. 2004.

28. Root MJ, Kay MS, Kim PS. Protein design of an HIV-1 entry inhibitor. Science. 2001; 291:884888. [PubMed: 11229405]

29. Root MJ, Steger HK. HIV-1 gp41 as a target for viral entry inhibition. Curr. Pharm. Des. 2004; 10:1805-1825. [PubMed: 15180542]

30. Steger HK, Root MJ. Kinetic dependence to HIV-1 entry inhibition. J. Biol. Chem. 2006; 281:25813-25821. [PubMed: 16803885]

31. Hamburger AE, Kim S, Welch BD, Kay MS. Steric Accessibility of the HIV-1 gp41 N-trimer Region. J. Biol. Chem. 2005; 280:12567-12572. [PubMed: 15657041]

32. Eckert DM, Shi Y, Kim S, Welch BD, Kang E, Poff ES, Kay MS. Characterization of the steric defense of the HIV-1 gp41 N-trimer region. Protein Sci. 2008; 17:2091-2100. [PubMed: 18802030]

33. Kubetzko S, Sarkar CA, Plückthun A. Protein PEGylation decreases observed target association rates via a dual blocking mechanism. Mol. Pharmacol. 2005; 68:1439-1454. [PubMed: 16099846]

34. Simon M, Zangemeister-Wittke U, Plückthun A. Facile double-functionalization of designed ankyrin repeat proteins using click and thiol chemistries. Bioconjugate Chem. 2012; 23:279-286.

35. Schurr JM. The role of diffusion in bimolecular solution kinetics. Biophys. J. 1970; 10:700-716. [PubMed: 5475729]

36. Shoup D, Szabo A. Role of diffusion in ligand binding to macromolecules and cell-bound receptors. Biophys. J. 1982; 40:33-39. [PubMed: 7139033]

37. Fersht, A. Structure and Mechanism in Protein Science: A Guide to Enzyme Catalysis and Protein Folding. New York: W. H. Freeman and Company; 1999.

38. Shammas SL, Crabtree MD, Dahal L, Wicky BIM, Clarke J. Insights into Coupled Folding and Binding Mechanisms from Kinetic Studies. J. Biol. Chem. 2016; 291:6689-6695. [PubMed: 26851275]

39. Deng H, Liu R, Ellmeier W, Choe S, Unutmaz D, Burkhart M, Di Marzio P, Marmon S, Sutton RE, Hill CM, et al. Identification of a major co-receptor for primary isolates of HIV-1. Nature. 1996; 381:661-666. [PubMed: 8649511] 
40. Fitton AO, Hill J, Jane DE, Millar R. Synthesis of simple oxetanes carrying reactive 2-substituents. Synthesis. 1987:1140-1142.

41. Zhang W, Go ML. Quinone reductase induction activity of methoxylated analogues of resveratrol. Eur. J. Med. Chem. 2007; 42:841-850. [PubMed: 17316918]

42. Song HY, Ngai MH, Song ZY, MacAry PA, Hobley J, Lear MJ. Practical synthesis of maleimides and coumarin-linked probes for protein and antibody labelling via reduction of native disulfides. Org. Biomol. Chem. 2009; 7:3400-3406. [PubMed: 19675893]

43. Wurm F, Dingels C, Frey H, Klok H-A. Squaric Acid Mediated Synthesis and Biological Activity of a Library of Linear and Hyperbranched Poly(Glycerol)-Protein Conjugates. Biomacromolecules. 2012; 13:1161-1171. [PubMed: 22376203]

44. Wurm F, Nieberle J, Frey H. Double-Hydrophilic Linear-Hyperbranched Block Copolymers Based on Poly(ethylene oxide) and Poly(glycerol). Macromolecules. 2008; 41:1184-1188.

45. Pace CN, Vajdos F, Fee L, Grimsley G, Gray T. How to measure and predict the molar absorption coefficient of a protein. Protein Sci. 1995; 4:2411-2423. [PubMed: 8563639]

46. Champagne K, Shishido A, Root MJ. Interactions of HIV-1 inhibitory peptide T20 with the gp41 N-HR coiled coil. J. Biol. Chem. 2009; 284:3619-3627. [PubMed: 19073602]

47. Danial M, Root MJ, Klok H-A. Polyvalent Side Chain Peptide-Synthetic Polymer Conjugates as HIV-1 Entry Inhibitors. Biomacromolecules. 2012; 13:1438-1447. [PubMed: 22455441]

48. Edelhoch H. Spectroscopic determination of tryptophan and tyrosine in proteins. Biochemistry. 1967; 6:1948-1954. [PubMed: 6049437] 
a

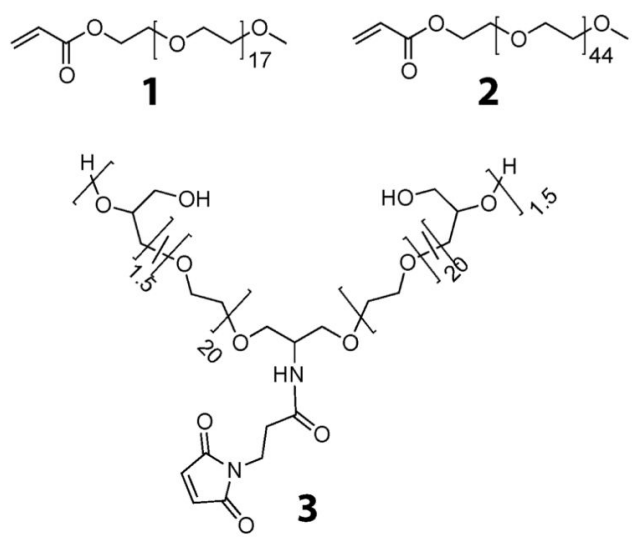

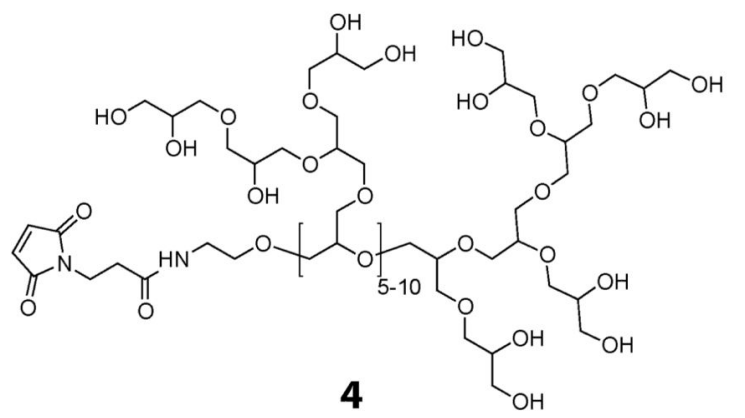

b $\quad$ gp41
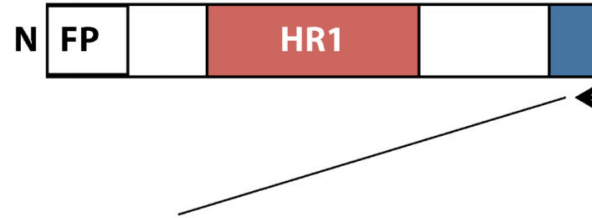

\section{HR2}

EWDREINNYTSLIHSLIEESQNQQEKNEQELLELDKWASLW

Wild type, C41

$\mathrm{N}$-terminus

C-terminus

CEWDREINNYTSLIHSLIEESQNQQEKNEQELLELDKWASLW

S15C

EWDREINNYTSLIHSLIEESQNQQEKNEQELLELDKW A SLWC

S20C

EWDREINNYTSLIHCLIEESQNQQEKNEQELLELDKWASLW

EWDREINNYTSLIHSLIEECQNQQEKNEQELLELDKWASLW

C
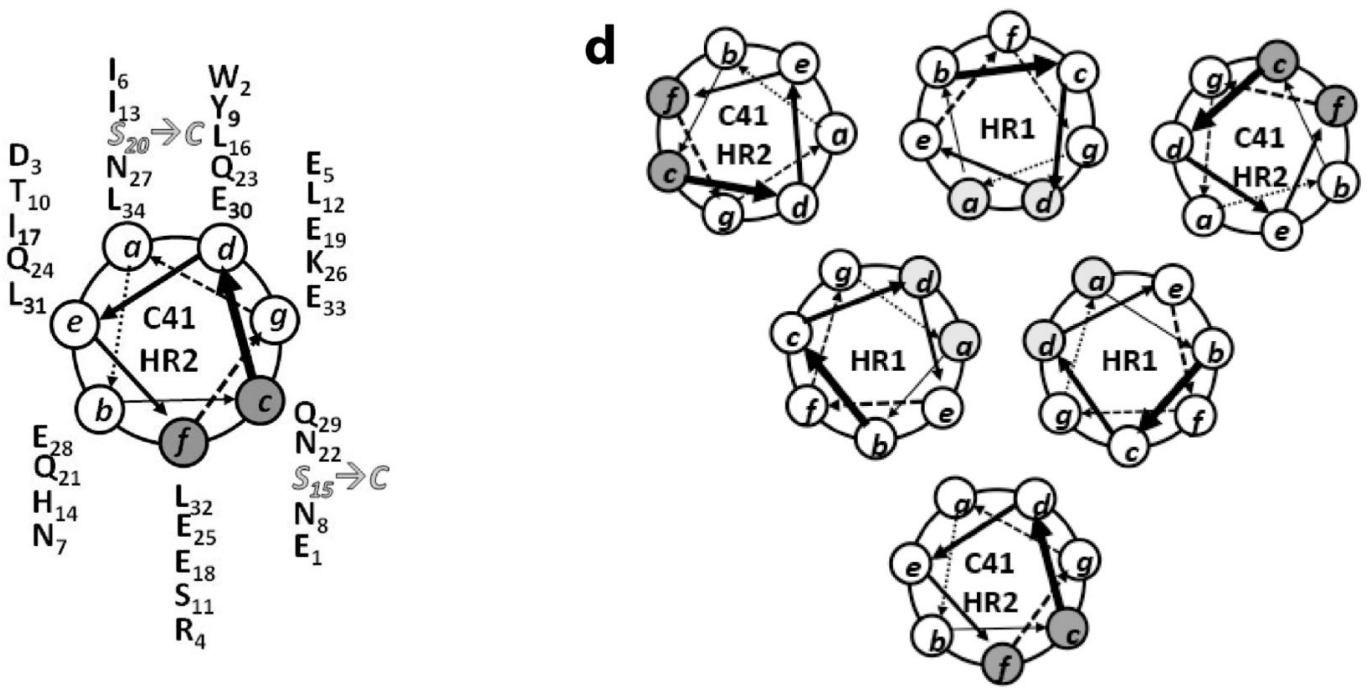

Figure 1.

(a) Structures of polymers including linear PEGs (1 and 2), mid-functional P(EG-co-G) (3), $h b \mathrm{PG}$ (4). (b) Sequences of the gp $41 \mathrm{HR} 2$ derived C41 cysteine variants. The sequence of the HR2 domain is defined as published, ${ }^{24}$ where $\mathrm{C} 41$ is a truncated version of the HR2 domain. (c) Helical wheel representation of $\mathrm{C} 41$ illustrating the location of the cysteine residues in S20C and S15C. (d) Helical wheel representation of the complex that is formed by binding of the $\mathrm{C} 41$ conjugate to the HR1 domains of the HIV-1 gp41. 


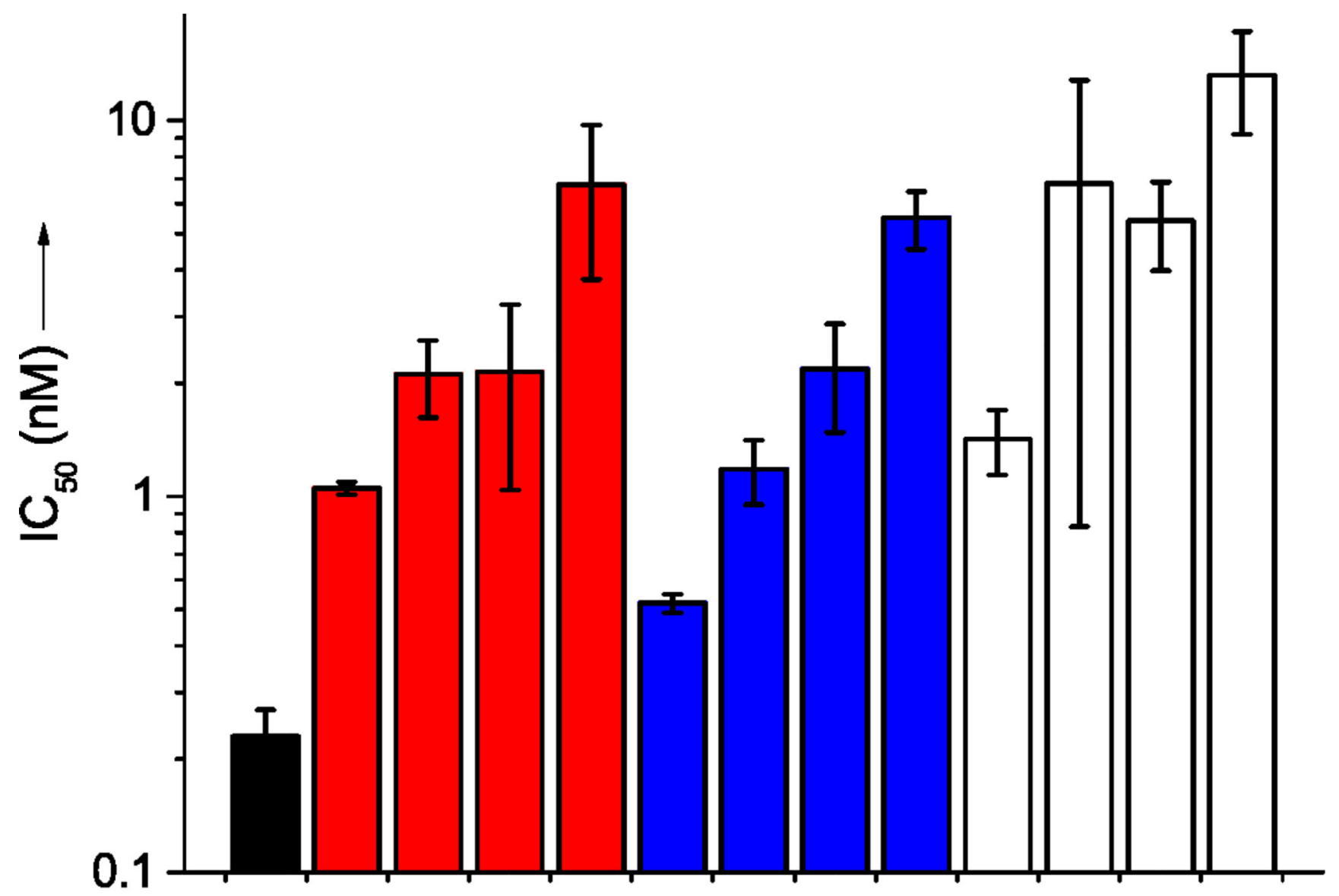

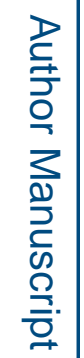

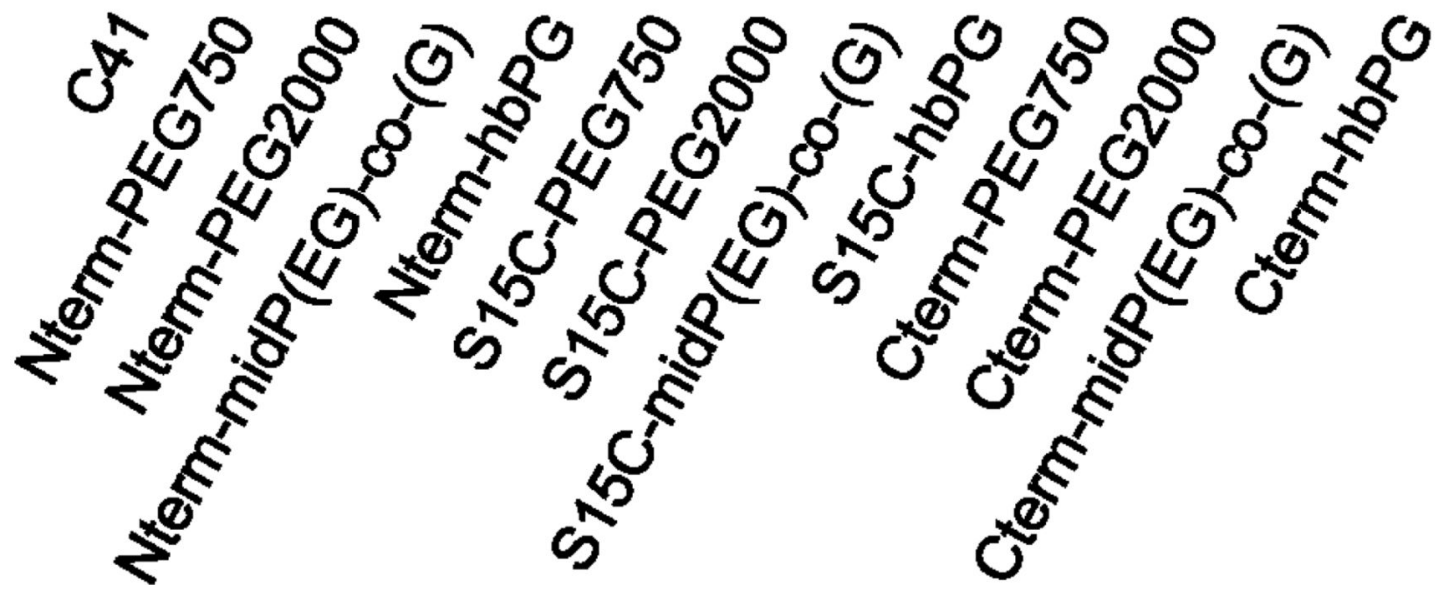

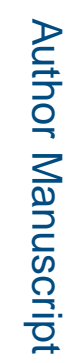

Figure 2.

Potency of the peptide - polymer conjugates against the fusion of HIV- $1_{\mathrm{HXB} 2}$. The black bars indicate the unmodified $\mathrm{C} 41$ peptide, red bars: N-terminal polymer conjugates, blue: S15C conjugates, white bars: C-terminal conjugates. The error bars indicate standard error of mean (SEM) of 3 or more independent experiments, each performed in duplicate. 


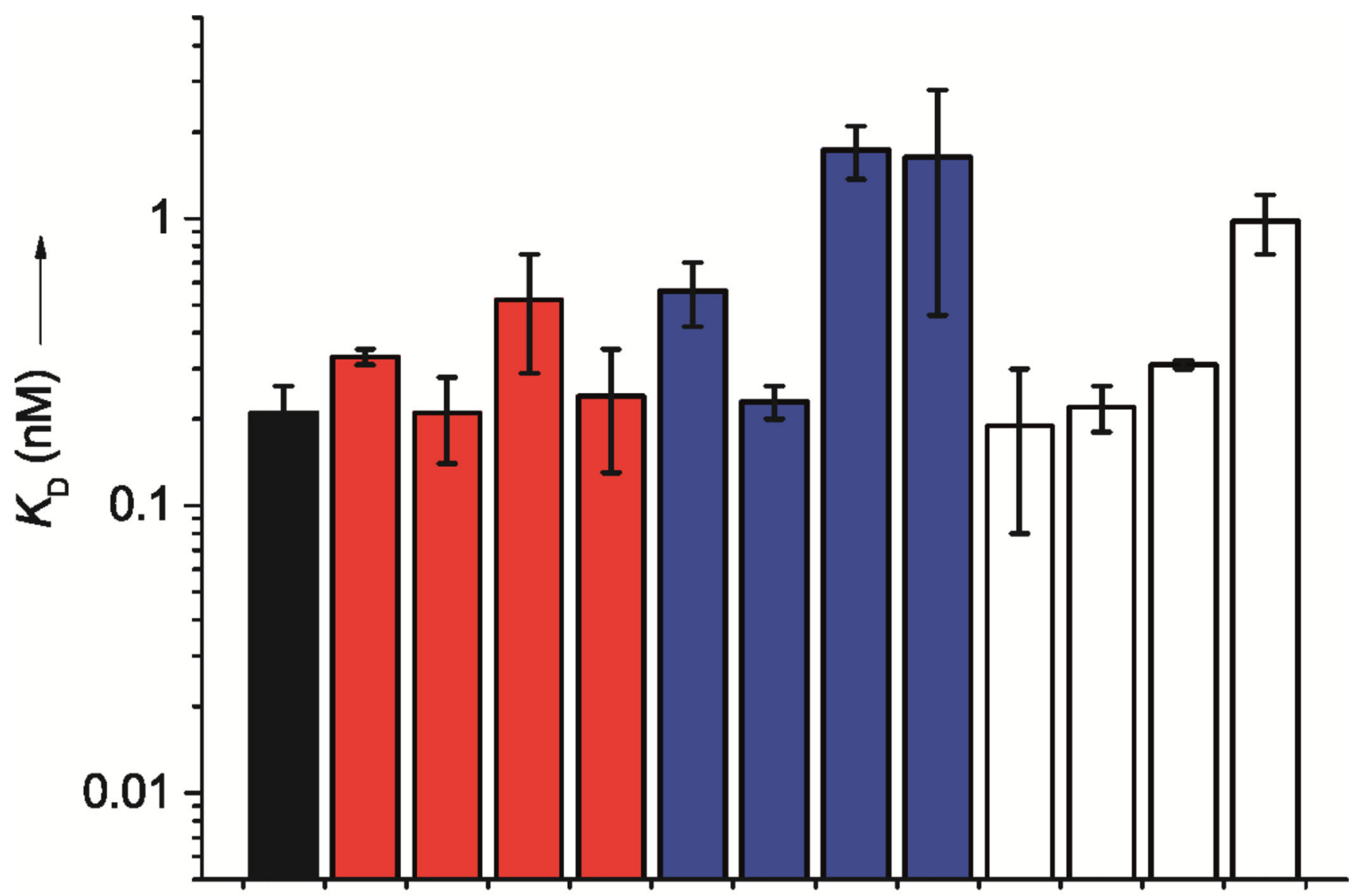

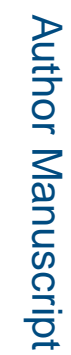

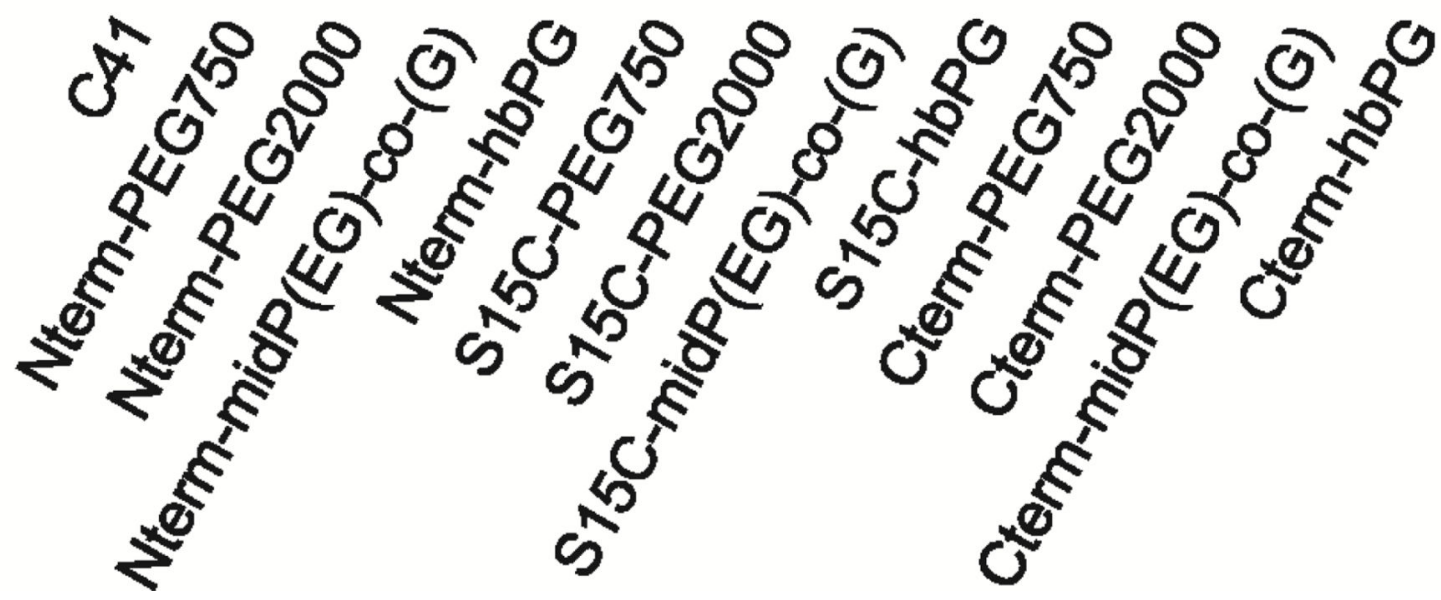

Figure 3.

Affinity of the peptide - polymer conjugates towards fluorescein modified 5-Helix. The black bars indicate the unmodified $\mathrm{C} 41$ peptide, red bars: N-terminal polymer conjugates, blue: S15C conjugates, white bars: C-terminal conjugates. The error bars indicate standard error of mean (SEM) of 3 or more independent experiments, each performed in duplicate. 


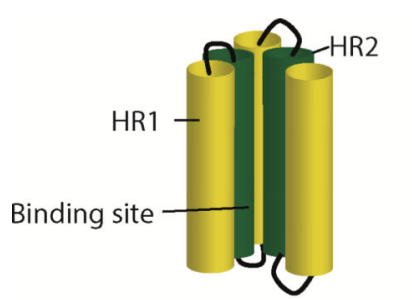

5-Helix
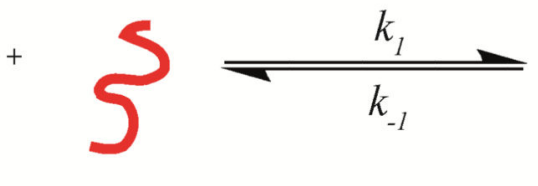

Peptide

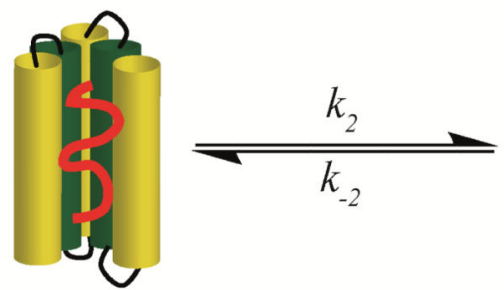

EC

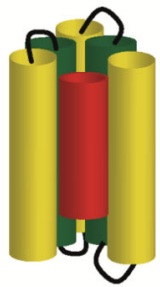

5-Helix $\cdot$ Peptide

Figure 4.

HR2 peptide binding model with 5-Helix. The HR2 peptide interacts with 5-Helix to form an encounter complex (EC). The peptide undergoes conformational changes to form a 5Helix - Peptide complex. 


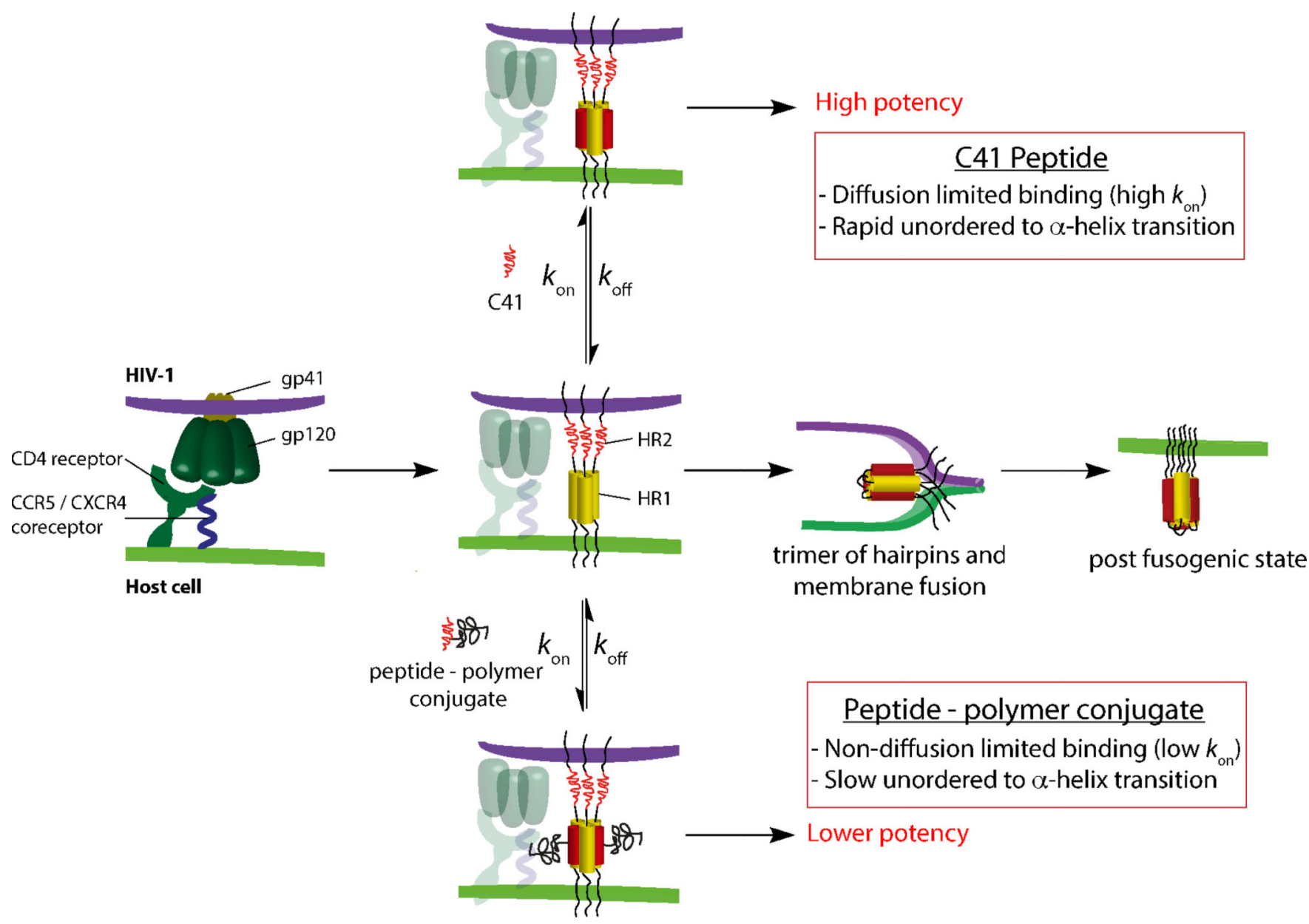

Figure 5.

Schematic representation of the HIV-1 membrane fusion and inhibition processes. The rate of association, $k_{\mathrm{on}}$ represents the binding process of $\mathrm{C} 41$ or peptide - polymer conjugate to the HR1 trimer on gp41. The dissociation rate, $k_{\mathrm{off}}$ represents the dissociation of the $\mathrm{C} 41$ or peptide - polymer conjugate from the HR1 domain on gp41. 


\section{Table 1}

Overview of the peptide - polymer conjugates investigated in this study.

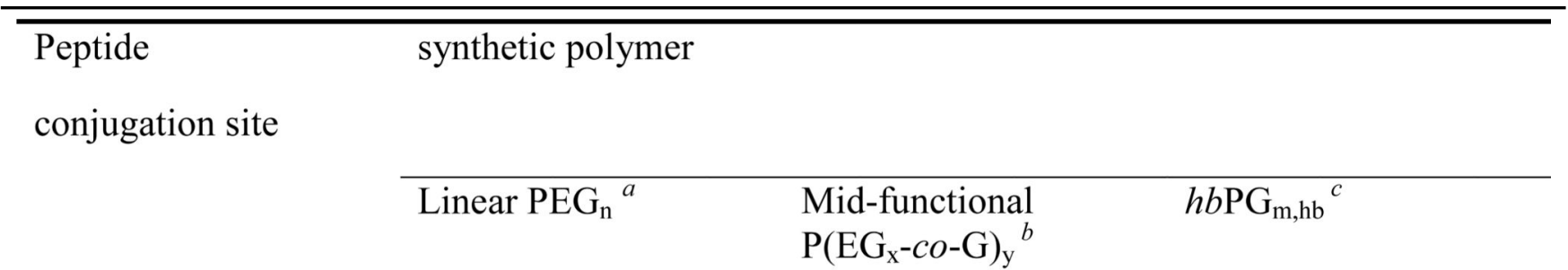

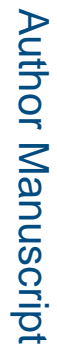

$\mathrm{N}$-terminus
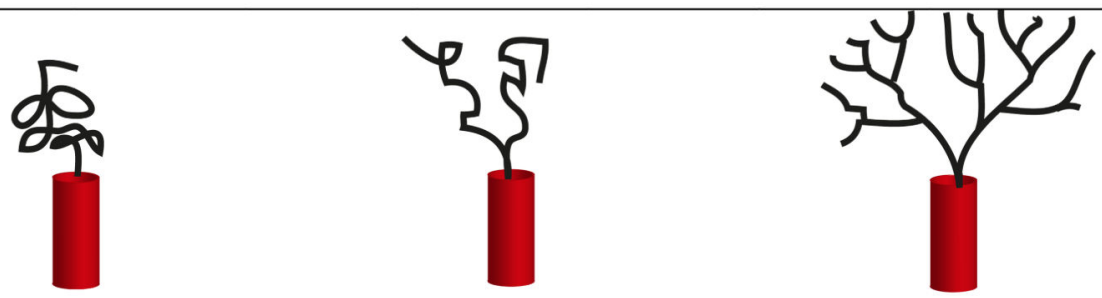

S15C
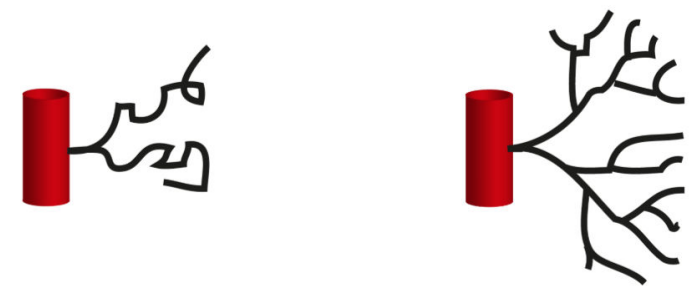

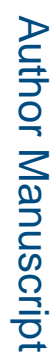

C-terminus
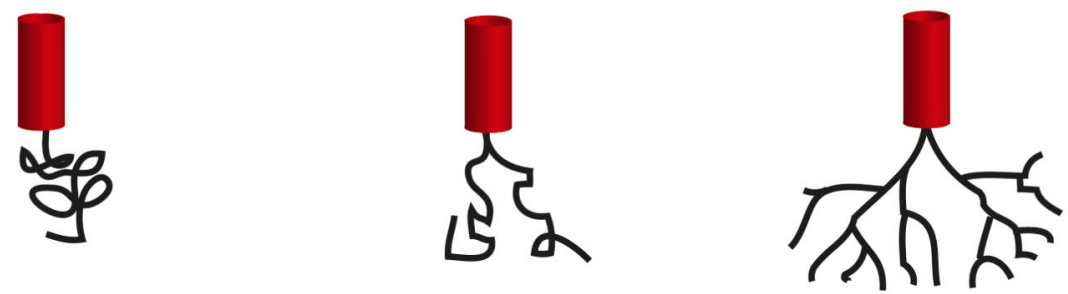

S20C
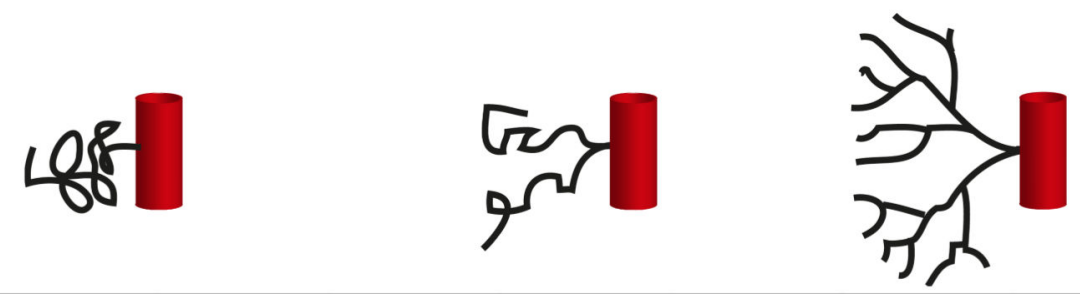

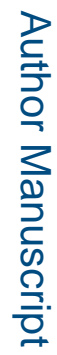

${ }^{a}$ PEG is monomethoxy-poly(ethylene glycol), where $\mathrm{n} \sim 17$ for PEG750 (1) and $\mathrm{n} \sim 45$ for PEG2000 (2).

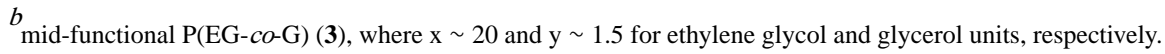

Bioconjug Chem. Author manuscript; available in PMC 2018 March 15. 
${ }_{h b \mathrm{PG}}^{c}(\mathbf{4})$, where $\mathrm{m}, \mathrm{hb}$ is $5-10$. The red cylinder moiety depicts peptide and black moiety depicts polymer. 


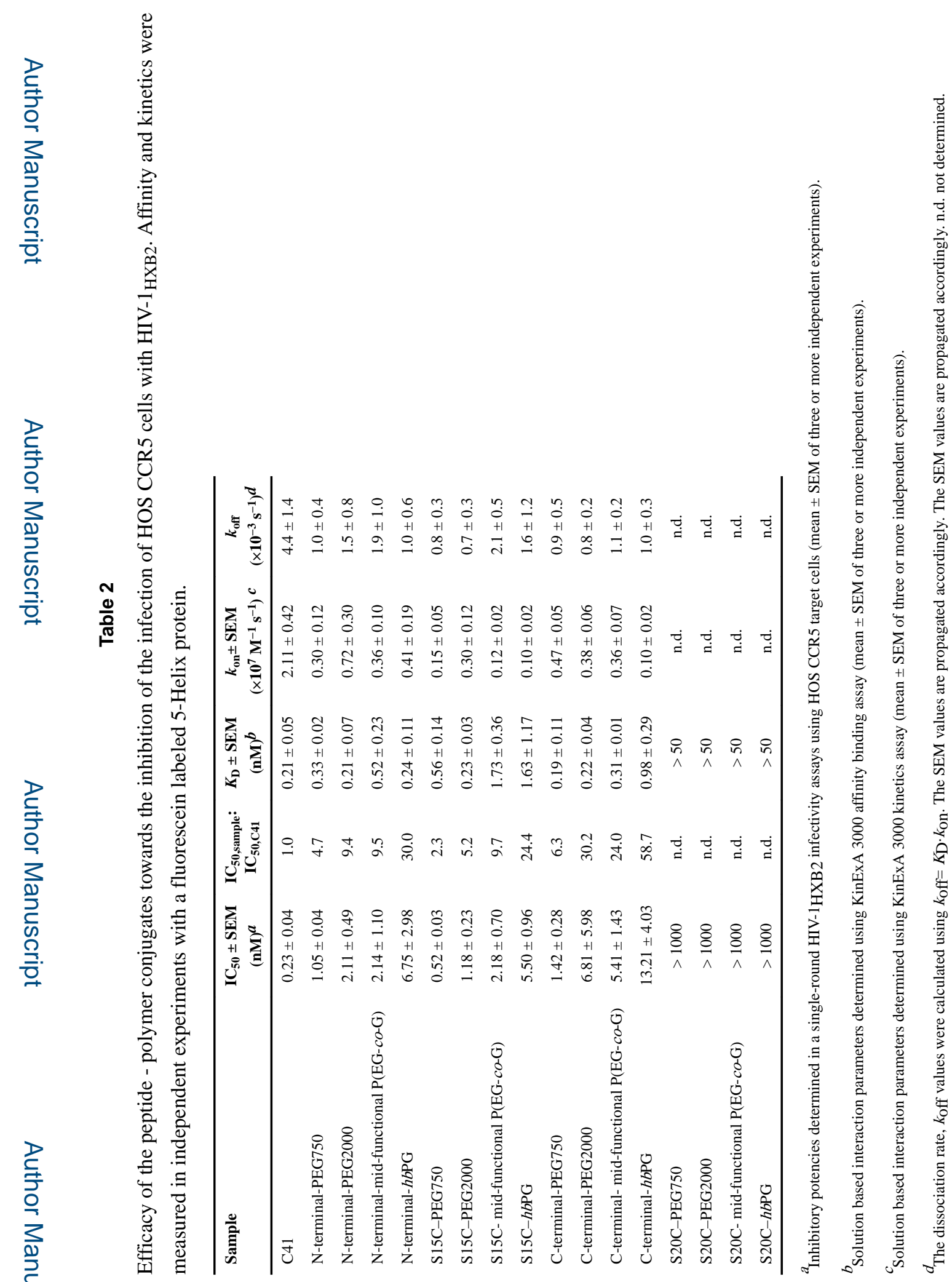

Bioconjug Chem. Author manuscript; available in PMC 2018 March 15. 